Erbaş, Y. H. (2021). Covid-19 salgını döneminde eğitim: İlkokuma yazma öğretiminde karşılaşılan sorunlar ve çözüm önerileri. Ana Dili Eğitimi Dergisi, 9(2), 360-380.

Ana Dili Eğitimi Dergisi
Journal of Mother Tongue Education
www.anadiliegitimi.com
Geliş/Received: 01.01 .2021 Kabul/Accepted: 16.02 .2021
Araştırma Makalesi / Research Paper

\title{
Covid-19 Salgını Döneminde Eğitim: İlkokuma Yazma Öğretiminde Karşılaşılan Sorunlar ve Çözüm Önerileri
}

\author{
Yahya Han ERBAŞ*
}

\begin{abstract}
Öz
Bu araştırmanın amacı, Covid-19 salgını döneminde uygulamaya konan acil uzaktan eğitim modelinde birinci sınıf öğretmenlerinin ilkokuma yazma öğretimi sırasında yaşadıkları sorunları ve çözüm önerilerini incelemektir. Bu çalışmanın katılımcıları, 2020-2021 eğitim-öğretim yılının güz döneminde sınıf öğretmenliğine halen devam eden, oluşturulan çevrimiçi formu gönüllü olarak doldurmayı kabul eden, Türkiye'nin yedi coğrafi bölgesinde görev yapmakta olan 111 birinci sınıf öğretmeni oluşturmaktadır. Araştırmada nitel araştırma modeli kullanılmış olup, veri toplama aracı olarak anket formu kullanılmıştır. Araştırmada veriler MAXQDA programı kullanılarak içerik analizi ile incelenmiştir. Araştırmanın bulgularına göre veliler, internet kaynakları, teknolojik araçlar, EBA, okul idaresi, yardımcı kaynak kitaplar, dijital içerikler, zümre öğretmenler, ders kitapları, sosyal medya, güdülenmiş öğrenci, yabancı dil bilgisi ve ailelere yardımcı olan üniversitelilerin varlığı birinci sınıf öğretmenlerine yardımcı olmuştur. Bunların dışında, İnternet bağlantı sorunları, internet yetersizliği, teknolojik araçlara sahip olmada eksiklik, ilgisiz veliler, sosyo-ekonomik durumlar ve öğrenci ile yeterli etkileşimin olmaması gibi nedenler birinci sınıf öğretmenlerine bu süreçte zorluk yaşatan durumlar olarak tespit edilmiştir. Ayrıca öğretmenlerin vermiş olduğu yanıtların analizi sonucunda acil uzaktan eğitim modeliyle kullandıkları ses temelli cümle yönteminin hecelerden kelimeler oluşturma basamağında çok zorlandıkları sonucuna ulaşılmıştır. Anahtar Kelimeler: Covid-19 salgını, ilkokuma yazma öğretimi, sınıf öğretmeni, uzaktan eğitim
\end{abstract}

\section{Education during the Covid-19 Pandemic: Problems Encountered in Reading and Writing Instruction and Suggested Solutions}

\section{Abstract}

This study aimed to examine the problems faced by first-grade teachers in teaching their students how to read and write via the government-mandated distance-learning program implemented during the Covid-19 pandemic and the strategies they followed to overcome these problems. The participants of this study consisted of 111 first-grade teachers serving in all seven of the Turkey's geographical regions during the fall semester of the 2020-2021 academic year who had volunteered to complete the online form for this study. Following a qualitative research model, this study employed a survey form to collect data, which were then analyzed using the software suite MAXQDA. The findings revealed that the teachers found the following factors helpful: parents, Internet resources, technological devices, EBA, school administrators, ancillary materials, digital content, department colleagues, textbooks, social media, motivated students, foreign language knowledge, and the existence of university students able to help families. However, they cited following factors as causing them difficulties: Internet connection problems, inadequate Internet connectivity, lack of technological devices, indifferent parents, socio-economic issues, and inadequate interaction with students. Furthermore, the responses that teachers gave following the

\footnotetext{
* Dr. Öğr. Üyesi, Çanakkale Onsekiz Mart Üniversitesi, Eğitim Fakültesi, Eğitim Bilimleri Bölümü, Çanakkale, yahyahan@gmail.com, ORCID: 0000-0003-0802-4536
} 
analysis revealed that they had trouble during the building-words-from-syllables phase of the sound-based sentence method used during distance learning.

Keywords: Covid-19 pandemic, teaching reading and writing, elementary school teacher, distance education

\section{Giriş}

Covid-19 adı verilen bir virüsün Aralık 2019'da Çin'in Wuhan şehrinde ortaya çıkması ve 11 Mart 2020 tarihinde Dünya Sağlık Örgütü'nün (WHO, 2020) tüm dünyada salgın ilan etmesiyle beraber birçok alanda tedbirler alınmaya başlamış, salgını yavaşlatmak hatta durdurmak üzere çeşitli görüşler ortaya atılmıştır. Salgının sadece sağılıkla ilgili alınması gereken tedbirlerden ibaret olmadığı, sosyal, politik, ekonomik ve eğitim alanlarında da çeşitli tedbirlerin alınması gerektiği bilinmektedir (Reimers ve Schleicher, 2020). Bu tedbirler kapsamında 1,6 milyar öğrencinin eğitim-öğretim faaliyetleri sekteye uğramış (United Nations Educational, Scientific and Cultural Organization [UNESCO], 2020a), mevcut durumdan dünyanın hemen hemen tamamı etkilenmiştir. Doğal olarak ülkemizde de bu süreçte salgınla mücadele adına eğitim acil uzaktan eğitim adıyla çevrimiçi olarak verilmeye başlanmış (Bozkurt, 2020a; Bozkurt vd., 2020; Bozkurt ve Sharma, 2020; Hodges, Moore, Lockee, Trust ve Bond, 2020), yaklaşık 16 milyona yakın okul öncesinden liseye kadar öğrenci bu durumdan etkilenmiştir (UNESCO, 2020b). 14 Mart 2020 tarihinde, üniversiteler dahil olmak üzere ülkemizde eğitim-öğretime ara verilmiştir. Illk başta eğitim-öğretim faaliyetlerine üç hafta ara verildiği ilan edilmesine rağmen, vaka sayılarındaki artış sebebiyle 2019-2020 eğitim öğretim yılının bahar döneminde okulların tekrar açılmaması kararı alınmıştır. Bununla birlikte hızlı bir karar alma süreci yaşanmış, acil uzaktan eğitim modeli ile eğitim-öğretime devam edilmesi sağlanmıştır (Eken, Tosun ve Tuzcu-Eken, 2020).

Yaşanan bu Covid-19 salgını sürecinde, ilkokuldan üniversiteye kadar verilecek eğitimin tek tip olmasının ihtimal dahilinde olmadığı bilinmektedir. Her çocuğun ve eğitim seviyesinin kendilerine özel beklentileri ve buna göre uyarlanmış bir eğitim alma durumları söz konusudur (Daniel, 2020). Buna bağıı olarak, eğitimcilerin güncel duruma göre çocukların ihtiyaçları doğrultusunda çeşitli eğitimlerden geçip, durumun oluşturduğu yeni rollere hazır hâle getirilmesi araştırmacılar tarafından tavsiye edilmiştir (Darling-Hammond ve Hyler, 2020). Korkmaz ve Toraman (2020, s.299), salgın sürecinde Türkiye'de halihazırda görevde olan eğitimcilerin deneyimlerini analiz ettikleri çalışmada, öğretmenlerin hızlı bir şekilde online eğitime geçilmesine hazırlıksız yakalandıklarını, çevrimiçi öğrenmenin henüz hazır olmadığını, eğitimcilerin acil uzaktan eğitim deneyimlerinin olmadığını, kullanılan sistemlerin kullanıcılara zor geldiğini, öğrencilerle etkileşimin düşük olduğunu, değerlendirmenin nasıl yapılacağını bilmediklerini ve uzaktan eğitimin her alan için mümkün olmadığını da içeren toplam 24 problem durumunu ortaya koymuşlardır. Öğretmenlerin uzaktan eğitime dair düşüncelerini analiz edilen çalışmalarda, kısıtlı zaman diliminde ders işleme, internet bağlantı sorunları, öğrencilerin dikkatlerini toplamada yaşanan güçlükler, materyal sıkıntısı, kontrolün sağlanamaması ve kazanımlara ulaşılamaması salgın sürecinde yaşanan sorunlar olarak belirlenmiştir (Demir ve Öztaş, 2020; Kurnaz, Kaynar, Şentürk-Barışık ve Doğrukök, 2020).

Sirem ve Baş (2020) yaptıkları araştırmada uzaktan eğitim sürecinde okuma güçlüğü çeken öğrencilerin deneyimlerini incelemişlerdir. Bu araştırmanın bulgularına göre okuma güçlüğü çeken öğrenciler "“'okuldan ayrı kalmaları kendini kötü ve üzgün hissetmelerine, yalnız kalma hissi ve arkadaşlarından ayrı kalma hissi duymalarına ve can sıkıntısı yaşamalarına sebep olmuştur" (s.1006) bulgularına ulaşarak bu sürecin etkilenenleri arasında her yaşantıdan öğrencinin olduğunu göstermişlerdir. Bir diğer çalışmada da Pınar ve Dönel-Akgül (2020) uygulamaya dönük içeriğe daha çok sahip olan fen derslerinin acil uzaktan eğitim ile uygulanması noktasında öğrenci görüşlerini incelemişlerdir. Çalışmanın sonuçlarına göre öğrencilerin deney yapamıyor olmaları, yaşanan teknik sorunlar, fırsat eşitliğinin temin edilememesi, odaklanma sorunu ve uzun süre dijital araç kullanımının fiziksel olarak verdiği zararları belirten birçok olumsuz deneyimlerden bahsettikleri görülmektedir.

Covid-19 salgını döneminde ilkokul öğretmenleriyle yapılan çalışmaları incelediğimizde, ilkokul öğretmenlerinin internet bağlantısındaki sorunlardan, değerlendirmenin objektif kriterlerden uzak kaldığından, öğrencinin öğrenip öğrenemediğinin tam bilinememesinden, konuların derinlemesine incelenememesinden, eğlenceli etkinliklerin yeterince uygulanamamasından, bireysel farklılıkların 
gözetilememesinden, öğrencilerin daha çok dinleyen (pasif) durumda olmasından şikayet ettikleri sonuçlarına ulaşılmıştır (Fauzi ve Khusuma, 2020; Yurtbakan ve Akyıldız, 2020). Sınıf öğretmenlerinin yaşadığı bu sorunları incelediğimizde, özellikle Covid-19 salgını döneminde birinci sınıf öğretmenlerinin yaşadıkları zorlukların ayrıca incelenmesi gerektiği zorunluluğu ortaya çıkmıştır. Bu sürecin bir diğer önemli bileşeni olan öğretmenlerin Covid-19 salgını hakkında görüşleri Akkaş-Baysal ve Ocak (2020) tarafından incelenmiş olup, öğretmenlerin yaşanan acil uzaktan eğitim sürecinin kendilerinde okula karşı özlem duygularını tetiklediğini, okulla olan bağları arasında bir kopma yaşandığını, derslere karşı öğrenciler gibi ilgisizliklerinin artığını ve çeşitli korkularının ortaya çıktığı sonucuna ulaşmışlardır.

Günbaş ve Gözüküçük (2020), salgın döneminde velilerin ilkokula giden çocuklarının acil uzaktan eğitim kapsamında deneyimlerini inceledikleri çalışmada, velilerin bu süreçte EBA bağlantı hatalarından, internet yetersizliğinden, canlı derslere katılım gösterirken yaşanan aksaklıklardan, ailelerin yeterli teknolojik bilgiye sahip olmamasından, evde öğrenci olan çocuk başına düşen dijital aracın yetersizliğinden, yazılımların hatalarından, ders materyallerine istenildiği şekilde erişim sağlanamamasından ve son olarak zamanın yeterli olmamasından şikayetçi oldukları bulgularına ulaşmışlardır. Bu olumsuzluklara bağlı olarak çocukların odaklanma sorunu yaşadıklarını, eğitimöğretim faaliyetlerini ciddiye almadıklarını, pasif dinleyici konumunda olmalarına bağlı olarak sınıf ortamına yabancılaştıklarını ve bu sebeplere bağlı olarak isteksizleştiklerini bildirmişlerdir. Bu türden aksaklıklara bağlı olarak ortaya çıkan isteksizliği aşmanın, çocuklara uzaktan da olsa eğitim almanın önemli olduğunun öğretilmesi, öğretmenleriyle iletişim kanallarının sürekli açık tutulması ve motive edici etmenlerin artırılmasıyla mümkün olacağı belirlenmiştir.

Illkokuma yazma öğretiminin farklı yöntem ve tekniklerin işe koşulmasıyla geliştirilen bir beceri olduğu bilinmektedir (Altunkaynak ve Çağımlar, 2020). Bu becerinin elde edilmesi sürecinde kullanılabilecek araçlardan biri de ilkokuma yazma özelinde geliştirilen dijital ürünlerdir. Bu ürünlerin kullanımı noktasında sını öğretmenlerinin "orta" seviyede ilişkili olduğu sonucunu bulan Altunkaynak ve Çağımlar (2020), sınıf öğretmenlerinin bu tür dijital içerik kullanımını artırmalarını tavsiye etmektedirler. Yaşanan bu salgın döneminin getirdiği şartlar göz önünde bulundurulursa bu tavsiyenin acilen uygulamaya geçmesi gerçeğini doğurmuştur.

Bununla beraber, Covid-19 salgını döneminde ilkokul öğretmenlerinin karşılaştıkları sorunları inceleyen çalışmaların henüz istenen seviyeye ulaşmadığı görülmektedir. Özellikle birinci sınıf öğretmenlerinin ilkokuma yazma öğretimi konusunda acil uzaktan eğitim sürecinde karşılaştıkları sorunlara dair bulgular araştırmalarda yer almamaktadır. İlkokuma yazma öğretimi gibi çocuğun bütün akademik başarılarını etkileyeceği bir dönemde acil uzaktan eğitim vermenin güçlüklerinin incelenmesi, bu güçlüklere karşı öğretmenlerin neler yaptıkları ve uzaktan eğitimin ilerleyen yıllarda bir ihtimal olarak devam etmesi durumunda öncelikli olarak ne gibi tedbirlerin alınması gerektiğinin incelenmesi amaçlanarak bu çalışma planlanmıştır. Bu amaçlar doğrultusunda aşağıdaki sorulara cevap aranmıştır:

1. Birinci sınıf öğretmenlerine Covid-19 salgınında uygulamaya konan acil uzaktan eğitim sürecinde ilkokuma yazma öğretiminde yardımcı olan etmenler nelerdir?

2. Birinci sınıf öğretmenlerine Covid-19 salgınında uygulamaya konan acil uzaktan eğitim sürecinde ilkokuma yazma öğretimine engel olan etmenler nelerdir?

3. Birinci sınıf öğretmenleri Covid-19 salgınında uygulamaya konan acil uzaktan eğitim sürecinde ses temelli cümle yöntemiyle okuma yazma öğretiminin hangi basamak ya da basamaklarında zorluk yaşadılar? Bu zorlukları aşmak için ne tür yöntemler kullandılar?

4. Birinci sınıf öğretmenlerine göre Covid-19 salgınıyla uygulamaya konan acil uzaktan eğitimin devam etmesi durumunda, ilkokuma yazma öğretiminin devam edebilmesi adına ne tür tedbirler alınmalıdır?

\section{Araştırmanın Modeli}

\section{Yöntem}

Araştırmada nitel araştırma modeli kullanılmış olup, durum çalışması olarak desenlenmiştir. Yıldırım ve Şimşek (2018) durum çalışmasını var olan bir ya da birden fazla durumun derinlemesine incelenmesi ve "bir duruma ilişkin etkenler (ortam, bireyler, olaylar, süreçler vb.) bütüncül bir yaklaşımla araştırılır ve ilgili durumu nasıl etkiledikleri ve ilgili durumdan nasıl etkilendikleri üzerine 
odaklanma" (s.73) olarak tanımlamaktadırlar. Bu çalışma da birinci sınıf öğretmenlerinin yaşanan Covid-19 salgını sürecinde uygulanan acil uzaktan eğitimde ilkokuma ve yazma öğretimine dair görüşlerinin derinlemesine incelenmesi üzerine kurulduğundan, nitel araştırma modelinin durum çalışması deseni olarak planlanmıştır.

\section{Katılımcılar}

Bu çalışmada "amaçsal örnekleme" (purposeful sampling)" (Büyüköztürk, Kıllı̧-Çakmak, Akgün, Karadeniz ve Demirel, 2020, s.92, Creswell,2012, s.206) yaklaşımının "kartopu örnekleme (snowball sampling)" (Creswell, 2012, s.209) yöntemi kullanılarak görev yapmakta olan birinci sınıf öğretmenlerine ulaşılmak istenmiştir. Kartopu örnekleme yöntemi, araştırmacının katılımcılardan bir ya da birkaçı ile iletişime geçerek, amaca uygun diğer katılımcıları önermeleri ile ortaya çıkan amaçsal örnekleme yaklaşımının bir şeklidir (Creswell, 2012, s. 209). Bulunan ilk birinci sınıf öğretmenlerinin iletişime geçilmesini tavsiye ettiği, Türkiye'nin çeşitli bölgelerinde görev yapan diğer uygun katılımcılara ulaşılarak, çalışma hakkında bilgi verilmiştir. Araştırmaya katılmaya gönüllü olan öğretmenlere hazırlanan çevrimiçi form gönderilerek daha çok veriye ulaşılmak amaçlanmıştır. Bu basamaklar sırasıyla takip edilerek, 2020-2021 eğitim-öğretim yılında sınıf öğretmenliğine halen devam eden, oluşturulan çevrimiçi formu gönüllü olarak doldurmayı kabul eden, Türkiye'nin yedi coğrafi bölgesinde görev yapmakta olan 130 sınıf öğretmeniyle iletişim kurulmuştur. Illk aşamada, 130 öğretmen tarafından doldurulan formlar, konuyla alakasız olanların, mantıklı dayanağı olmayan ve eksik bilgiler veren 19 sınıf öğretmeninin formu değerlendirilmeye alınmayarak toplamda 111 öğretmenden veri toplanmıştır. Kullanılması uygun görülen formlar SÖ1, SÖ2, SÖ3,....., SÖ111 şeklinde gerçek isimler yerine kodlanmıştır.

Araştırmaya katılan öğretmenlerimizin $75^{\prime} \mathrm{i}(\% 67,6)$ kadın, 36'sı $(32,4)$ erkek birinci sınıf öğretmenlerdir. Türkiye'nin 7 coğrafi bölgesinin tamamından sınıf öğretmenlerinin katılım gösterdiği, lisans mezunu $(n=105, \% 94,6)$ ve yüksek lisans mezunu $(n=6, \% 5,4)$ olan, resmi $(n=102, \% 91,9)$ ve özel kurumlarda $(n=9, \% 8,1)$ çalışan öğretmenler yer almaktadır.

\section{Veri Toplama Aracı}

Bu çalışmada veri toplama aracı olarak anket formu kullanıımıştır. Thomas'a (1998) göre anket "insanların yaşam koşullarını, davranışlarını veya tutumlarını betimlemeye yönelik bir dizi sorudan oluşan bir araştırma materyalidir" (akt. Büyüköztürk vd, 2020, s.129). Bu çalışma için oluşturulan anket soruları demografik özellikleri belirlemeye yarayan olgusal, katılımcıların bir konudaki bilgilerini belirlemek için bilgi sorularından oluşturulmuştur (Büyüköztürk vd., 2020). Bu soru şekilleri göz önünde bulundurularak, araştırmada sınıf öğretmenlerinin Covid-19 salgınında uygulamaya konan acil uzaktan eğitim sürecinde ilkokuma yazma öğretimine yönelik deneyimleri ile ilgili görüşlerini incelemek amacıyla geliştirilen anket formu kullanılmıştır.

\section{İşlem / Verilerin Toplanması}

Araştırmacı tarafından oluşturulan anket formu, çalışmaya katılmaya gönüllü olduğunu beyan eden birinci sınıf öğretmenlerine 06.12.2020-12.12.2020 tarihleri arasında ulaştııılmıştır. Burada gelen yanıtlarla beraber araştırmacı verileri incelemeye başlamış ve sık tekrarların olmaya başladığı fark edildiği anda veri doygunluğuna ulaşıldığı anlaşıımış olup, çevrimiçi forma veri kabulü durdurulmuştur.

\section{Verilerin Analizi}

Araştırmanın verilerinin analizinde içerik analizi kullanılmıştır. Yıldırım ve Şimşek (2018), içerik analizinin "toplanan verileri açıklayabilecek kavramlara ve ilişkilere ulaşmak" (s.242) olarak tanımlamıştır. Bu araştırmada, Yıldırım ve Şimşek'in (2018) belirlediği dört aşamalı analiz kullanılmıştır. İlk aşamada verilerin tamamı incelenip, bölümlere ayrılarak o bölümlerin altında yatan anlamlar bulunmuştur. Daha sonra bu anlamlı kısımlara tanımlayıcı isimlerle kodlar verilmiştir. Devamında araştırmacı bu kodları bir araya getirerek belirli kategoriler altında toplayarak temalara ulaşmıştır. Bu işlemlerin yapılması sırasında, nitel veri analiz programlarından MAXQDA kullanılmış olup, elde edilen 
sonuçlar oluşturulan kodlar kelime bulutlarına dönüştürülmüştür. Daha sonra bu kodlardan meydana gelen temalar tablolar şeklinde gösterilmiştir.

\section{Geçerlik ve Güvenirlik}

Anket formu açık uçlu sorulardan oluşmuştur ve bu dönemde karşılaşılması muhtemel durumlar doğrultusunda hazırlanmıştır. Geçerliği ve güvenirliği sağlamak amacıyla nitel araştırmalarda sıkıkla kullanılan uzman incelemesi ve katılımcı teyidi stratejileri kullanılmıştır. İlk önce analiz sonucu ortaya çıkan kodlar, kategoriler ve temalar planlanan bir zamanda araştırmacı tarafından düzenlenen bir toplantı ile iki farklı alan uzmanının incelemesine sunulmuş olup, alan uzmanlarının geri bildirimleri doğrultusunda aralarındaki benzerliklere ve farklılıklara bakıımıştır. Ortaya çıkan farklılıklar konusunda alan uzmanlarıyla fikir alışverişinde bulunularak ortak bir fikirde buluşma sağlanmıştır. Ayrıca araştırmaya katılan sekiz birinci sınıf öğretmeni tarafından ortaya çıkan kodlar, kategoriler ve temalar incelenerek görüşleri alınmıştır. Geçerlik ve güvenirlik için katıımcı teyidi alınan birinci sınıf öğretmenleri, ortaya çıkan kodların, kategorilerin ve temaların uygunluğu konusunda görüş bildirmişlerdir. Araştırmanın bulgular kısmında, katılımcı birinci sınıf öğretmenlerinin görüşlerinden doğrudan alıntılar yapılarak geçerlik ve güvenirlik sağlanmak istenmiştir.

\section{Araştırma ve Yayın Etiği}

Bu çalışmada "Yükseköğretim Kurumları Bilimsel Araştırma ve Yayın Etiği Yönergesi" kapsamında uyulması belirtilen tüm kurallara uyulmuştur. Yönergenin ikinci bölümü olan "Bilimsel Araştırma ve Yayın Etiğine Aykırı Eylemler" başlığı altında belirtilen eylemlerden hiçbiri gerçekleştirilmemiştir. Çalışmaya katılan sınıf öğretmenlerinden gönüllülük esasına göre izinleri alınmıştır.

\section{Etik Kurul İzi}

Kurul adı = Çanakkale Onsekiz Mart Üniversitesi Bilimsel Araştırmalar Etik Kurulu

Karar tarihi $=04.12 .2020$

Belge sayı numarası $=06 / 31$

\section{Bulgular}

Araştırmanın alt problemlerine ait bulgulara bu bölümde yer verilmiştir.

\section{Birinci Sınıf Öğretmenlerine Acil Uzaktan Eğitimde Yardımcı Olan Etmenler}

Araştırmanın birinci alt probleminde birinci sınıf öğretmenlerinin acil uzaktan eğitim sürecinde yardımcı olan etmenlerle ilgili görüşleri alınmış ve elde edilen kodlar şekil 1'deki gibi oluşturulan kelime bulutlarıyla (www.wordart.com) gösterilmektedir. Kelime bulutları oluşturulurken çeşitli yazılımların ve web sayfalarının ürünleri incelenmiş olup, bu araştırmaya uygun görsellerin belirtilen kaynakta oluşturulmasına karar verilmiştir. Takip eden bütün kelime bulutları bu web sayfası üzerinde oluşturulmuştur.

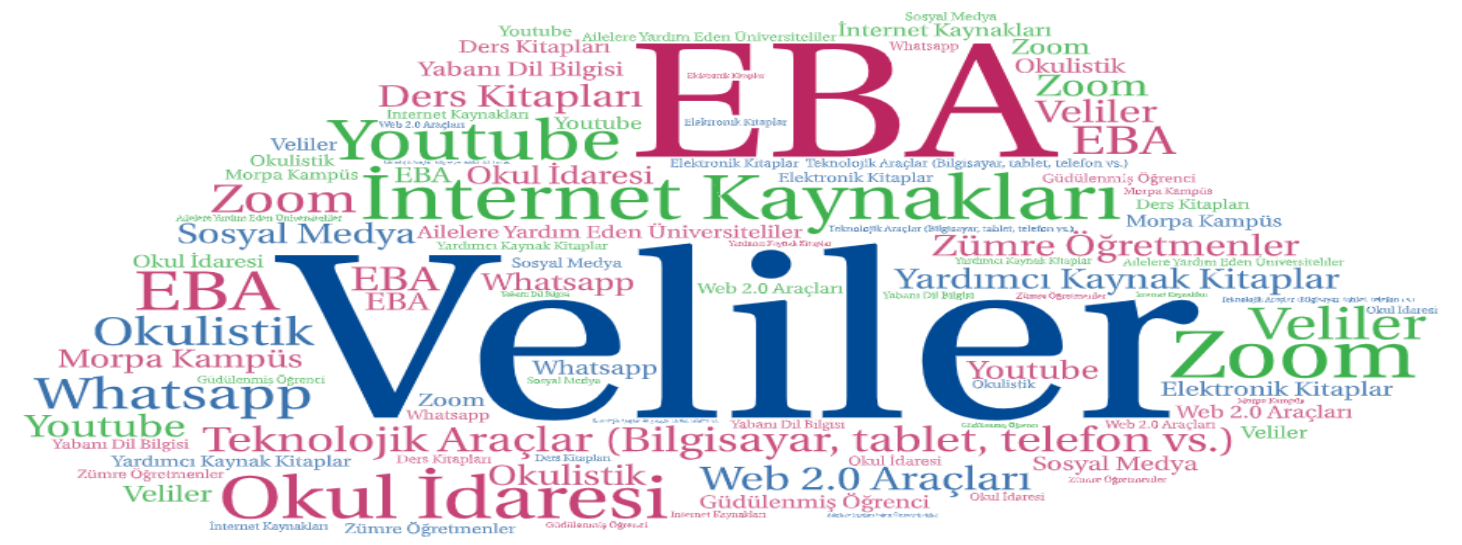

Şekil 1. Birinci Sınıf Öğretmenlerine Yardımcı Olan Etmenler 
Şekil 1'de öğretmenlere yardımcı olan unsurların kodlanmasıyla ortaya çıkan kavramlardan elde edilen kelime bulutu yer almaktadır. Kelime bulutunda öğretmenlerin sıklıkla bahsettiği, frekansı yüksek kavramlar büyük puntolarla ifade edilirken, yardımcı olan etmenlerin sıklığı azaldıkça punto büyüklüğü de küçülmektedir. Öğretmenlerimizin bir veya birden fazla kendilerine yardım eden kavram belirlemiş olup, toplamda 195 ifade elde edilmiştir.

Şekil 1'i incelediğimizde, birinci sınıf öğretmenlerinin kendilerine yardımcı olduğunu söylediği kavramlar sırasıyla şunlardır; veliler ( $n=41, \% 21,0)$, internet kaynakları $(n=35, \% 17,9)$, teknolojik araçlar (bilgisayar, tablet, telefon vs.) ( $n=32, \% 16,4)$, EBA $(n=14, \% 7,2)$, okul idaresi $(n=11, \% 5,6)$, yardımc। kaynak kitaplar $(n=10, \% 5,1)$, youtube $(n=7, \% 3,6)$, zümre öğretmenler $(n=6, \% 3,1)$, web 2.0 araçları $(n=6, \% 3,1)$, whatsapp $(n=5, \% 2,6)$, zoom $(n=5, \% 2,6)$, ders kitapları $(n=4, \% 2,1)$, sosyal medya $(n=4$, $\% 2,1)$, morpa kampüs $(n=4, \% 2,1)$, güdülenmiş öğrenci $(n=3, \% 1,5)$, okulistik $(n=3, \% 1,5)$, elektronik kitaplar $(n=3, \% 1,5)$, yabancı dil bilgisi $(n=1, \% 0,5)$ ve ailelere yardım eden üniversiteliler $(n=1, \% 0,5)$. Öğretmenlerin kendilerine acil uzaktan eğitim sürecinde yardım eden etmenleri incelediğimizde, en çok yardımı velilerden ve internette yer alan çeşitli web sitelerindeki kaynakların yaptığını söyleyebiliriz. Buradan ortaya çıkan kodların kategorilere ayrılmasıyla elde edilen temalar tablo 1'de verilmiştir.

Tablo 1.

Sınıf öğretmenlerine yardımcı olan etmenlerden oluşan temalar

\begin{tabular}{lll}
\hline Temalar & Kategoriler & Kodlar \\
\hline Altyapı Kaynaklı Destekler & Eğitim Amaçlı Yazılımlar & EBA \\
& & Zoom \\
& & Youtube \\
\cline { 2 - 3 } & Iletişım Amaçlı Yazılımlar & Whatsapp \\
\hline Aile Kaynaklı Destekler & Aile Bireyleri Arası Dayanışma & Veliler \\
& & Güdülenmiş Öğrenci \\
\cline { 2 - 3 } & Ailenin Ekonomik Durumu ile & Teknolojik Araçlar (bilgisayar, tablet, \\
& ilgili Durumlar & telefon vs.) \\
\hline Eğitim-Öğretim & Ücretli Eğitim Kaynakları & Morpa Kampüs \\
Destekler & & Okulistik \\
& & Elektronik Kitaplar \\
& & Web 2.0 Araçları \\
& & Yardımcı Kaynak Kitaplar \\
& & Yabancı Dil Bilgisi \\
\cline { 2 - 3 } & Bireysel Yeteneğe Dayanan & Okul Idaresi \\
\hline Kurumsal Destekler & Eğitim Kaynağı & Zümre Öğretmenler \\
& Kurum Çalışanları & Ders Kitapları \\
\cline { 2 - 3 } & Kurumun Sağladığı Olanaklar & Sosyal Medya \\
& İnternet Kaynakları \\
\cline { 2 - 3 } & Paylaşım &
\end{tabular}

Tablo 1'de de görüldüğü üzere birinci sınıf öğretmenlerinin görüşleri doğrultusunda altyapı kaynaklı destekler, aile kaynaklı destekler, eğitim-öğretim faaliyetleri kaynaklı destekler, kurumsal destekler ve toplumsal destekler olmak üzere beş ana tema ortaya çıkmıştır. Temalarımızı incelediğimizde, sınıf öğretmenlerinin görüşleriyle kendilerine yardımcı olan etmenlere bağlı olarak ortaya çıkan kodların en çok "eğitim-öğretim faaliyetleri kaynaklı destekler" temasında, en az "toplumsal destekler" temasında toplandığını görmekteyiz. Bazı öğretmenlerimizin görüşlerine aşağıda yer verilmiştir. 
"Bu süreçte velilerimizin vermiş olduğu destekler sayesinde, öğrencilerimize bu dönemi en az hasarla atlattırmayı amaçlıyoruz. Velilerimizin iş harici kalan zamanlarını verimli kullanmak için çaba gösterdiklerini görmek, beni daha çok çaba göstermeye teşvik ediyor." (S.Ö.14, K)

"Veli whatsapp grupları her ne kadar yönetmesi zor bir ortam olsa da çocuklara ve velilere ulaşmak için velinimet niteliğinde. Oradan gerekli bilgi paylaşımını yaparak çocuklarına derse hazır etmeleri sorunları bir nebze azaltmaktadır." (S.Ö.7, K)

"Bilgisayar iyi kullanabilmem, araştırma yapmayı seviyor olmam, velilerimin ders sürecine önem vermesi, ögrrencilerimin öğrenmeye istekli olması, okul idaresinin canlı derslere karşı olan hassasiyeti sayesinde ilkokuma ve yazma öğretimini mümkün olduğunca iyi yürütmeye çalışıoruz." (S.Ö.25, K)

"En büyük yardımcı unsur velidir bence bu süreçte. Kendi çocuğuna değer veren bir veli varsa ortada tüm imkanlarını kullanır. Ve idare ile zümrelerin ortaklaşa çalışması da çok önemlidir." (S.Ö.103, K)

"internetteki bütün uygulama ve etkinlikleri çocuklara ulaştırma şansımız oluyor sadece tek bir etkinlikle bir dersi işlemek yerine bir kaç etkinlik ve uygulama ile dersi zenginleştirebiliyoruz uzaktan eğitim ile." (S.Ö.12, K)

\section{Birinci Sınıf Öğretmenlerine Acil Uzaktan Eğitimde Engel Olan Etmenler}

Araştırmanın ikinci alt probleminde birinci sınıf öğretmenlerinin acil uzaktan eğitim sürecinde engel olan etmenlerle ilgili görüşleri alınmış ve elde edilen kodlar şekil 2'deki (www.wordart.com) gibi gösterilmiştir.

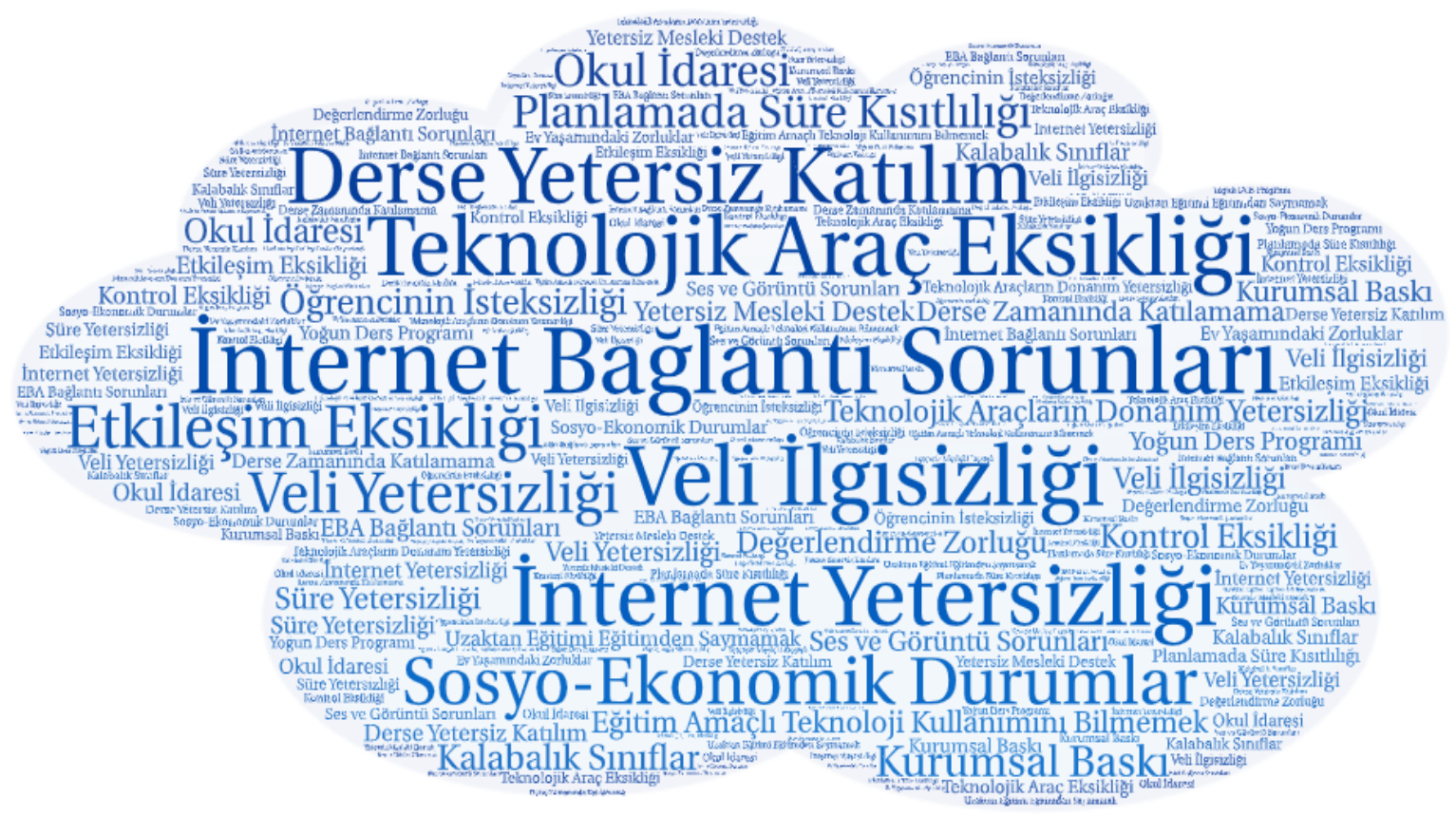

Şekil 2. Sınıf Öğretmenlerine Engel Olan Etmenler

Şekil 2'de öğretmenlere engel olan etmenlerin kodlanmasıyla ortaya çıkan kavramlardan elde edilen kelime bulutu yer almaktadır. Öğretmenlerimizin bir veya birden fazla kendilerine yardım eden kavram belirlemiş olup, toplamda 176 ifade elde edilmiştir. Buna göre öğretmenlerimiz bu süreçte, internet bağlantı sorunlarının ( $n=30, \% 17,0)$, internet yetersizliğinin $(n=24, \% 13,6)$, teknolojik araca sahip olmadaki eksikliğin ( $n=21, \% 11,9)$, veli ilgisizliğinin $(n=14, \% 8,0)$, sosyo-ekonomik durumların ( $n=12, \% 6,8)$, derse yetersiz öğrenci katılımının $(n=11, \% 6,3)$, eğitim amaçlı teknoloji kullanmayı bilmemenin ( $n=9, \% 5,1)$, teknolojik araçların donanım yetersizliği $(n=10, \% 5,7)$, öğrenci ile yeterli etkileşimin olmamasının $(n=8, \% 4,5)$, velilerin bilgi yetersizliğinin $(n=7, \% 4,0)$, planlamada sürenin yetersiz olmasının $(n=7, \% 4,0)$, öğrencinin katılımdaki isteksizliğinin ( $n=5, \% 2,8)$, derse zamanında katılamamanın $(n=3, \% 1,7)$, değerlendirmenin zor olmasının $(n=3, \% 1,7)$, kurumsal baskının $(n=3$, 
$\% 1,7)$, ses ve görüntü sorunlarının ( $n=2, \% 1,1)$, acil uzaktan eğitimi eğitimden saymamanın $(n=2, \% 1,1)$, okul idaresinin ( $n=2, \% 1,1)$, kontrol eksikliğinin $(1, \% 0,6)$, kalabalık sınıfların $(n=1, \% 0,6)$, ev yaşamının zorluklarının ( $n=1, \% 0,6)$, EBA bağlantı sorunlarının $(n=1, \% 0,6)$, yetersiz mesleki desteğin $(n=1, \% 0,6)$ ve yoğun ders programının $(n=1, \% 0,6)$ ilkokuma yazma öğretiminde kendilerine engel olan etmenler olduğunu belirtmişlerdir. Öğretmenlerin kendilerine acil uzaktan eğitim sürecinde engel olan etmenleri incelediğimizde, en çok internet bağlantı sorunlarının kendilerine engel teşkil ettiğini beyan etmişlerdir. Buradan ortaya çıkan kodların kategorilere ayrılmasıyla elde edilen temalar tablo 2'de verilmiştir.

Tablo 2.

Sını öğretmenlerine engel olan etmenlerden oluşan temalar

\begin{tabular}{|c|c|c|}
\hline Temalar & Kategoriler & Kodlar \\
\hline \multirow{6}{*}{$\begin{array}{l}\text { Altyapıdan } \\
\text { Kaynaklanan } \\
\text { Sorunlar }\end{array}$} & Kamu Hizmeti Kapsamında & İnternet Bağlantı Sorunları \\
\hline & Yaşanan Sorunlar & Teknolojik Araçların Donanım Yetersizliği \\
\hline & & EBA Bağlantı Sorunları \\
\hline & & Internet Yetersizliği \\
\hline & Ekonomik Durumlar Kapsamında & Teknolojik Araç Eksikliği \\
\hline & Yaşanan Sorunlar & Ses ve Görüntü Sorunları \\
\hline \multirow{4}{*}{$\begin{array}{l}\text { Aileden } \\
\text { Kaynaklanan } \\
\text { Sorunlar }\end{array}$} & Öğrencinin Sorumluluğunda Olan & Derse Zamanında Katılamama \\
\hline & Durumlar & Derse Yetersiz Katılım \\
\hline & Velilerin Sorumluluğunda Olan & Veli İlgisizliği \\
\hline & Durumlar & Acil Uzaktan Eğitimi Eğitimden Görmemek \\
\hline \multirow{7}{*}{$\begin{array}{l}\text { Eğitim-Öğretim } \\
\text { Faaliyetlerinden } \\
\text { Kaynaklanan } \\
\text { Sorunlar }\end{array}$} & Öğretmen Yeterliğinden & Eğitim Amaçlı Teknoloji Kullanımını \\
\hline & Kaynaklanan Durumlar & Bilmemek \\
\hline & & Değerlendirme Zorluğu \\
\hline & Dersi Yönetiminden Kaynaklanan & Planlamada Süre Kısıtlılığı \\
\hline & Sorunlar & Etkileşim Eksikliği \\
\hline & & Öğrencilerin Eksikliği \\
\hline & & Kontrol Eksikliği \\
\hline \multirow{5}{*}{$\begin{array}{l}\text { Yetkililerden } \\
\text { Kaynaklanan } \\
\text { Sorunlar }\end{array}$} & Okulların Yapısından Kaynaklanan & Yoğun Ders Programı \\
\hline & Durumlar & Kalabalık Sınıflar \\
\hline & Çalışanlar Arası İletişimden & Okul İdaresi \\
\hline & Kaynaklanan Durumlar & Kurumsal Baskı \\
\hline & & Yetersiz Mesleki Destek \\
\hline \multirow{3}{*}{$\begin{array}{l}\text { Toplumsal } \\
\text { Kaynaklı } \\
\text { Sorunlar }\end{array}$} & $\begin{array}{l}\text { Veli Eğitiminden Kaynaklanan } \\
\text { Durumlar }\end{array}$ & Veli Yetersizliği \\
\hline & Günlük Yaşamdan Kaynaklanan & Sosyo-Ekonomik Durumlar \\
\hline & Durumlar & Ev Yaşamının Zorlukları \\
\hline
\end{tabular}

Tablo 2'de görüldüğü üzere birinci sınıf öğretmenlerinin görüşleri doğrultusunda altyapıdan kaynaklı sorunlar, aileden kaynaklı sorunlar, eğitim-öğretim faaliyetlerinden kaynaklı sorunlar, yetkililerden kaynaklı sorunlar ve toplumsal kaynaklı sorunlar olmak üzere beş ana tema belirlenmiştir. Temalarımızı incelediğimizde, sınıf öğretmenlerinin görüşleriyle kendilerine engel olan etmenlere bağlı olarak ortaya çıkan kodların en çok eşit sayıda kod içeren "altyapıdan kaynaklı sorunlar" ve "eğitimöğretim faaliyetlerinden kaynaklanan sorunlar" temalarında, en az "toplumsal kaynaklı sorunlar" temasında toplandığını görmekteyiz. Bazı öğretmenlerimizin görüşlerine aşağıda yer verilmiştir.

"Internet kesintisi, bağlantı sorunları, ders ortasında derse katılım, kullanılan programlardan kaynaklı ses ve görüntü sorunları nedeniyle dersler yeterince verimli olmuyor." (S.Ö5, K) 
"Canlı derse öğrencilerin bağlanamaması, öğrencilerin motivasyonlarını sağlamada zorlukların yaşanması ve aileden birileri olmadan ders yapılamaması bu süreçte bizleri en çok engelleyen durumlardır." (S.Ö38, E)

"Öğrenciyle temas yok. Kontrol bizde değil. Bizim yönlendirmelerimizle velinin becerisine kalmış her şey. Veli ne kadar anlayışlıysa ve yetenekliyse eğitim o kadar oluyor." (S.Ö.53, E)

"Özellikle interneti olmayan öğrencilerim bu süreçte oldukça zorlandılar, bu beni de engelledi. Ayrıca sistemdeki bazı eksiklikler ses sorunları gibi unsurlar verimi düşürdü." (S.Ö59, E)

"Internet erişimi olmayan bir köyde eğitim veriyor olmam. Aile bireylerinin ekonomik durumu, velilerin teknolojiye yabancı olup çocuklara destek olamaması, aynı öğrencinin abisi/ablasının üst sınıflarda olup derse katılabilecekse de önceliğin ona verilmesi gibi durumlarla mücadele etme noktasında çok zorlandım." (S.Ö.66, K)

"Dersleri yaparken bir çok teknik sorunla mücadele etmek yetmiyormuş gibi, M.E.B.'in aldığı kararların uygulamadaki zorlukları da bu sorunların katlanarak büyümesine neden oluyor." (S.Ö.110, E)

\section{Acil Uzaktan Eğitimde Ses Temelli Cümle Yöntemi Zorlukları ve Çözüm Önerileri}

Araştırmanın üçüncü alt probleminde öğretmenlerimizin ilkokuma yazma öğretiminde kullanılan ses temelli cümle yönteminin "ilkokuma yazmaya hazırlık, ilkokuma-yazmaya başlama, sesi hissetme ve tanıma, sesi okuma ve yazma, sesten heceler oluşturma, hecelerden kelimeler oluşturma, kelimelerden cümleler oluşturma ve metin oluşturma" aşamalarından hangisi ya da hangilerinde zorlandıklarına dair veriler şekil 3'te, bu zorlukları aşmak için ne tür yöntemler kullandıkları hakkında görüşlerine dair elde edilen veriler şekil 4'te (www.wordart.com) gösterilmiştir.

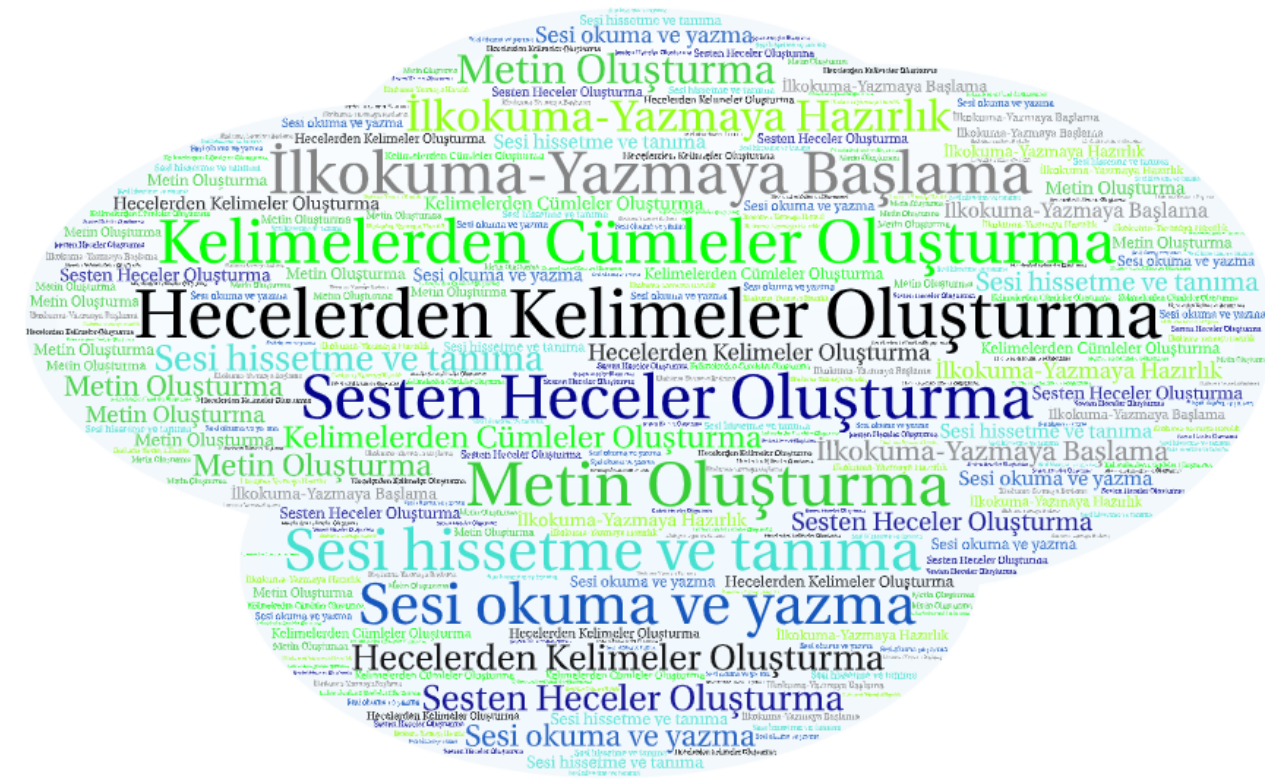

Şekil 3. Sınıf Öğretmenlerine Engel Olan Etmenler

Şekil 3'te birinci sınıf öğretmenlerinin acil uzaktan eğitim sürecinde ilkokuma yazma öğretiminde kullanılan ses temelli cümle yönteminin gerekli adımlarından hangisinde ya da hangilerinde daha çok zorlandığı sorulmuştur. Öğretmenlerin vermiş olduğu yanıtların analizi sonucunda sırasıyla hecelerden kelimeler oluşturma $(n=43, \% 38,7)$, sesten heceler oluşturma $(n=38$, $\% 34,2)$, kelimelerden cümleler oluşturma $(n=34, \% 30,6)$, metin oluşturma $(n=34, \% 30,6)$, ilkokumayazmaya başlama $(n=29, \% 26,1)$, sesi hissetme ve tanıma $(n=27, \% 24,3)$, sesi okuma ve yazma $(n=27$, $\% 34,2)$ ve ilkokuma-yazmaya hazırlık $(n=22, \% 19,2)$ basamaklarında zorlandıklarını belirtmişlerdir. Öğretmenlerin acil uzaktan eğitim sürecinde ilkokuma yazma öğretiminin hecelerden kelimeler oluşturma basamağında zorlandığı ortaya çıkmıştır. 
Katılımcıların yukarıda belirttikleri ses temelli cümle yönteminin aşamalarında yaşadıkları zorlukları en aza indirmek hatta yok etmek için ne tür yöntemler kullandıkları ile ilgili görüşleri alınmış ve elde edilen verilere dair bilgiler şekil 4 'te (www.wordart.com) gösterilmiştir.

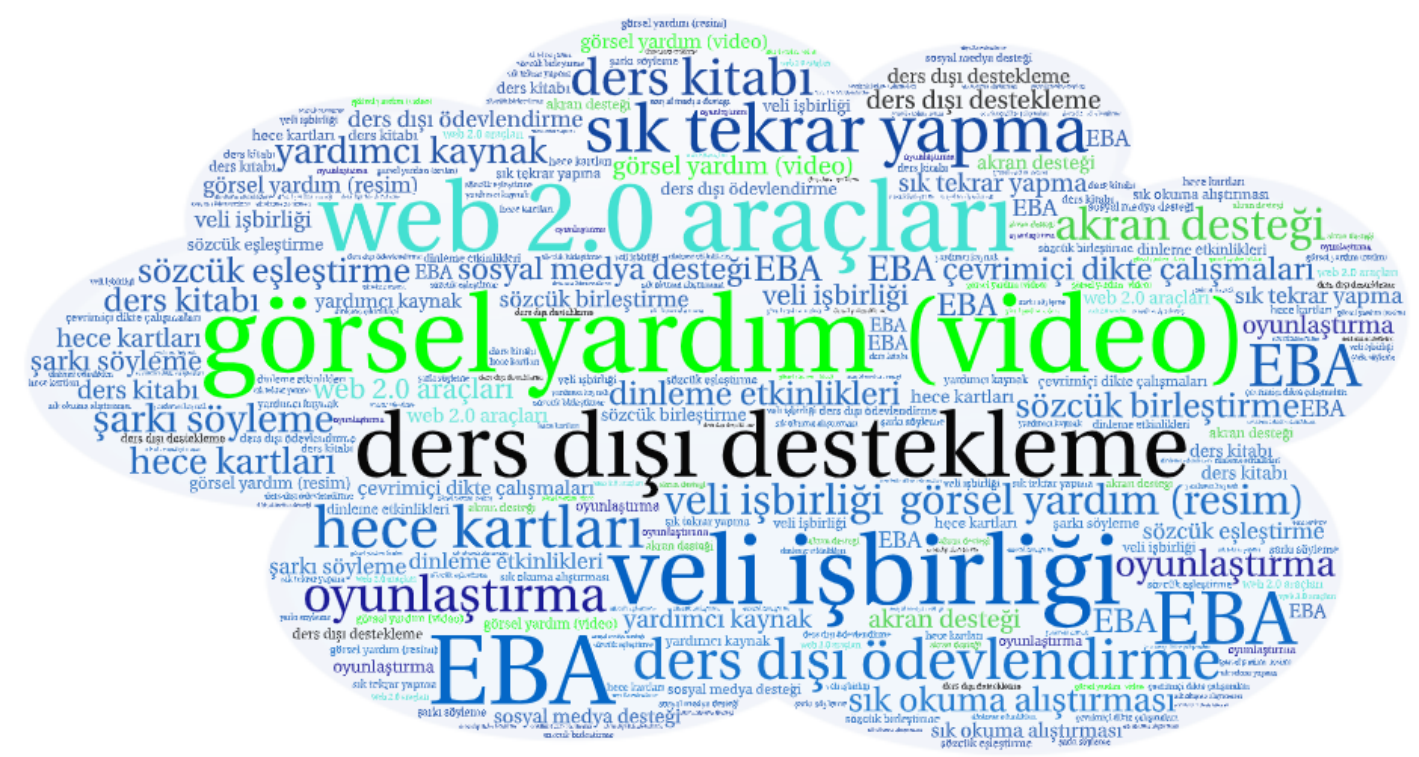

Şekil 4. Sınıf Öğretmenlerine Kullandıkları Yöntemler

Şekil 4'te sınıf öğretmenlerinin acil uzaktan eğitim sürecinde ilkokuma ve yazma öğretiminde kullandıkları ses temelli cümle yöntemiyle alakalı karşılaştıkları sorunlara karşı kullandıkları çözüm önerilerinden oluşan kelime bulutu yer almaktadır. Öğretmenlerimiz bir veya birden fazla çözüm önerilerinden bahsetmiş olup, toplamda 155 ifade elde edilmiştir. Buna göre öğretmenlerimiz bu süreçte, görsel yardım (video) ( $n=30, \% 19,4)$, veli işbirliği $(n=29, \% 18,7)$, ders dışı destekleme $(n=12$, $\% 7,7)$, web 2.0 araçları $(n=12, \% 7,7)$, ders dışı ödevlendirme $(n=11, \% 7,1)$, sık tekrar yapma $(n=10$, $\% 6,5)$, görsel yardım (resim) $(n=9, \% 5,8)$, hece kartları $(n=7, \% 4,5)$, çevrimiçi dikte çalışmaları $(n=7$, $\% 4,5)$, oyunlaştırma $(n=5, \% 3,2)$, EBA $(n=5, \% 3,2)$, sık okuma alıştırması $(n=5, \% 3,2)$, yardımcı kaynak $(n=4, \% 2,6)$, akran desteği $(n=4, \% 2,6)$, sosyal medya desteği $(n=1, \% 0,6)$, ders kitabı $(n=1, \% 0,6)$, sözcük birleştirme $(n=1, \% 0,6)$, sözcük eşleştirme $(n=1, \% 0,6)$, dinleme etkinlikleri $(n=1, \% 0,6)$ ve şarkı söyleme $(n=1, \% 0,6)$ yöntemlerini kullanarak yaşadıkları zorlukları aşmaya çalıştıklarını söylemişlerdir.

Buradan ortaya çıkan kodların kategorilere ayrılmasıyla elde edilen temalar tablo 3'te verilmiştir.

Tablo 3.

Acil uzaktan eğitimde ses temelli cümle yöntemi öğretimine ilişkin çözüm önerileri

\begin{tabular}{lll}
\hline Temalar & Kategoriler & Kodlar \\
\hline \multirow{3}{*}{$\begin{array}{l}\text { Teknolojik Araçlarla Bulunanmler } \\
\text { Yazılımın Aktif }\end{array}$} & Görsel Yardım (Video) \\
& Kullanımından Kaynaklı & $\begin{array}{l}\text { Görsel Yardım (Resim) } \\
\text { Web 2.0 Araçları }\end{array}$ \\
& & EBA \\
\cline { 2 - 3 } & $\begin{array}{l}\text { Eğitim Yazııımları } \\
\text { Kaynaklı }\end{array}$ & Çevrimiçi Dikte Çalışmaları \\
\hline Aile Destekli Bulunan & Aile Katılımı Kaynaklı & Veli İşbirliği \\
\cline { 2 - 3 } Çözümler & Aile-Öğretmen İşbirliği & Ders Dışı Destekleme \\
& Kaynaklı & \\
\hline
\end{tabular}

Şarkı Söyleme

Sık Tekrar Yapma 


\begin{tabular}{lll}
\hline & Sınıf-içi Etkinliklerin & Hece Kartları \\
Eğitim-Öğretim Etkinlikleri & Çevrimiçi Ortamlara & Oyunlaştırma \\
Destekli Çözümler & Uyarlanması & Sözcük Birleştirme \\
& & Dinleme Etkinlikleri \\
\cline { 2 - 3 } & Çevrimiçi Derslere Hazır & Ders Dışı Ödevlendirme \\
& Olmaya Yönelik & Sık Okuma Alıştırması \\
& Çözümler & Yardımcı Kaynak \\
& & Ders Kitabı \\
\hline Toplum Destekli Çözümler & Yaşam Çevresi Kaynaklı & Akran Desteği \\
\cline { 2 - 3 } & İletişim Araçları Kaynaklı & Sosyal Medya Desteği \\
\hline
\end{tabular}

Tablo 3'ü incelediğimiz zaman, teknolojik araçlarla bulunan çözümler, aile destekli bulunan çözümler, eğitim-öğretim etkinlikleri destekli çözümler ve toplumsal destekli çözümler olmak üzere dört tema ortaya çıkmıştır. Temalarımızı incelediğımizde, sınıf öğretmenlerinin görüşleriyle acil uzaktan eğitim sürecinde ses temelli cümle yönteminin kullanımıyla ilgili karşılaştıkları sorunlara dair çözüm önerileriyle ilgili kodların en fazla eğitim-öğretim etkinleri destekli çözümler teması altında toplanırken, en az 2'şer koda sahip olan temalar aile destekli bulunan çözümler ve toplumsal destekli çözümlerdir. Katılımcı öğretmenlerimizden bazılarına ait görüşlere aşağıda yer verilmiştir.

"Sesi hissettirme ve tanımada görseller ve videolar getirdim. Metin okumada sınıf mevcudum az olduğu için tek tek okuma yaptırdım. Harfleri tanımaları için oyunlaştırdım." (S.Ö.4, E)

"Defalarca tekrara başvurdum. Müfredata bağlı kalmaya çalıştım. Öğrenemediklerini fark ettiğim noktada çocuklara mantığını anlatmak için zaman harcadım. Öğrenemeyenleri tespit edip ailelere çektiğim videoları attım. Ders esnasında öğrenemeyenlere okuduktan sonra teyit ettirdim." (S.Ö.6, K)

"Dikte ettirmekte çok zorlandım bu yüzden dikte yaptırmayı hep ailelere bi görev olarak ilettim. Çocukların hepsinin seviyesi ve anlama süresi bir değil bu yüzden çocuklarla seslerden hece ve kelime oluştururken videolardan yararlanıp hepsinin hem ilgilerini çekmesini hem de bir kaç kez videoyu oynatarak pekiştirilmesini sağladım." (S.Ö.12, K)

"Ses birleştirme tekniklerinin üzerinde fazla durarak harici detaylı video üretimi yapıp paylaştım. Velilere önceliğin ses birleştirmeye verilmesi gerektiğini söyledim." (S.Ö.84, E)

"Bu zorlukları aşmak için her adımın fotoğraf ve videolarını istedim. Görmeden bir tedbir alamayacağım için. Çocuklar okurken videolar istedim ve dönütler verdim. Yazılarını görmek içinde aynı şekilde. Yazı yazarken dikkat etmeleri gereken noktalar konusunda velileri bilgilendirdim. Sesleri birleştiremeyen öğrencilerim için video, slayt ve oyunlar hazırlayıp velilerimle de paylaştım derste de kullandım." (S.Ö.99, K)

"Özellikle bilgisayardan somutlaştırma etkinlikleri yaptım. Ayrıca Whatsapp gruplarına videolar atarak destekledim. Son olarak fotokopi bırakarak onlara yardımcı oldum." (S.Ö.60, E)

"Ders kitabıyla birlikte iki farklı kaynaktan ders işliyorum. Öğrenciler birden fazla kaynaktan örnekler gördügü için heceleri okumaları daha kolay oluyor." (S.Ö.74, E)

"Sadece canlı derslerle kalmayıp aynı zamanda Whatsapp üzerinden de gerekli ses dosyalarını velilere göndererek çocukların sesleri daha doğru hissetmelerini sağladım." (S.Ö.36, K)

"Derslerime ilgilerini çekecek materyaller hazırladım, bol bol okuma ve dikte çalışması yaptırdım." (S.Ö.81, K)

\section{Gelecekte Uzaktan Eğitim ile Okuma Yazma Öğretiminde Alınması Gereken Tedbirler}

Araştırmanın dördüncü alt probleminde birinci sınıf öğretmenlerimizin uzaktan eğitim sürecinin ilerleyen yıllarda devam etmesi durumunda, eğitim-öğretimin devam edebilmesi adına ne tür tedbirlerin alınması gerektiği konusunda görüşleri incelenmiştir. Bu tedbirler hakkında görüşlerine dair elde edilen veriler şekil 5'te (www.wordart.com) gösterilmiştir. 


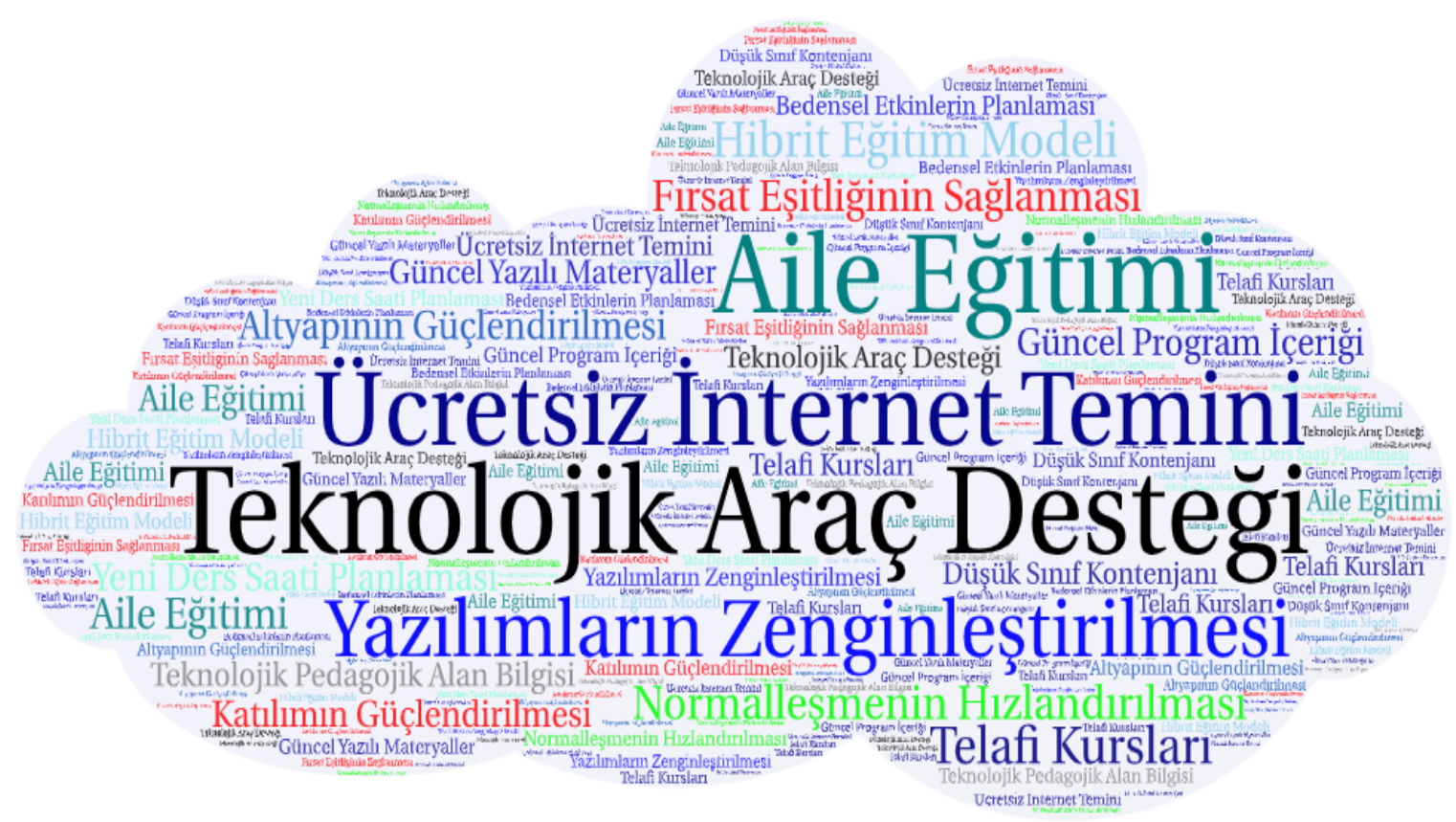

Şekil 5. Öğretmenlerce Belirlenen Alınması Gereken Tedbirler

Şekil 5'te birinci sınıf öğretmenlerinin uzaktan eğitim sürecinin devam etmesi durumunda ilerleyen dönemlerde ilkokuma yazma öğretiminin devam edebilmesi için alınması gereken tedbirlerden oluşan kelime bulutu yer almaktadır. Öğretmen görüşleri üzerinde yapılan kodlamalar sonucunda toplamda 190 kod elde edilmiştir. Bu kodların dağılımı şu şekilde olmaktadır: teknolojik araç desteği $(n=38, \% 20,0)$, ücretsiz internet temini $(n=27, \% 14,2)$, yazılımların zenginleştirilmesi $(n=17$, $\% 8,9)$, normalleşmenin hızlandırılması $(n=15, \% 7,9)$, aile eğitimi $(n=15, \% 7,9)$, altyapının güçlendirilmesi $(n=14, \% 7,4)$, fırsat eşitliğinin sağlanması $(n=12, \% 6,3)$, yeni ders saati planlaması $(n=10$, $\% 5,3)$, teknolojik pedagojik alan bilgisi ( $n=9, \% 4,7)$, katılımın güçlendirilmesi $(n=8, \% 4,2)$, hibrit eğitim modeli $(n=8, \% 4,2)$, güncel yazılı materyaller $(n=7, \% 3,7)$, güncel program içeriği $(n=6, \% 3,2)$, telafi kursları $(n=2, \% 1,1)$, düşük sınıf kontenjanı $(n=1, \% 0,5)$ ve son olarak bedensel etkinliklerin planlanması $(n=1, \% 0,5)$.

Buradan ortaya çıkan kodların kategorilere ayrılmasıyla elde edilen temalar tablo 4 'te verilmiştir.

Tablo 4.

ilkokuma yazma öğretiminde uzaktan eğitimin kullanımında alınması gereken tedbirler

\begin{tabular}{|c|c|c|}
\hline Temalar & Kategoriler & Kodlar \\
\hline \multirow{3}{*}{$\begin{array}{l}\text { Teknoloji Kapsamında } \\
\text { Yapılması Gerekenler }\end{array}$} & Özel Girişim-Devlet Odaklı & Yazılımların Zenginleştirilmesi \\
\hline & \multirow[t]{2}{*}{ Devlet Odaklı } & Altyapının Güçlendirilmesi \\
\hline & & Teknolojik Araç Desteği \\
\hline \multirow{4}{*}{$\begin{array}{l}\text { Aile Kapsamında } \\
\text { Yapılması Gerekenler }\end{array}$} & & Aile Eğitimi \\
\hline & & Katılımın Güçlendirilmesi \\
\hline & \multirow{2}{*}{$\begin{array}{l}\text { Öğretmen ve Okul } \\
\text { Kapsamında Yapılacaklar }\end{array}$} & Hibrit Eğitim Modeli \\
\hline & & Teknolojik-Pedagojik Alan Bilgisi \\
\hline \multirow{5}{*}{$\begin{array}{l}\text { Eğitim-Öğretim } \\
\text { Etkinlikleri Kapsamında } \\
\text { Yapılması Gerekenler }\end{array}$} & Ders Araç-Gereçleri ve İşleyiş & Güncel Yazılı Materyaller \\
\hline & Kapsamında Yapılacaklar & Bedensel Etkinliklerin Planlanması \\
\hline & Eşitliğin Temini Kapsamında & Fırsat Eşitliğinin Sağlanması \\
\hline & Yapılacaklar & Telafi Kursları \\
\hline & & Ücretsiz Internet \\
\hline
\end{tabular}




\begin{tabular}{lll}
\hline \multirow{3}{*}{$\begin{array}{l}\text { Yetkililerce Yapılması } \\
\text { Gerekenler }\end{array}$} & Eğitimin Yeni Duruma & $\begin{array}{l}\text { Güncel Eğitim Programı İçeriği } \\
\text { Uüşük Sınıf Kontenjanı } \\
\end{array}$ \\
\cline { 2 - 3 } & Yeni Ders Saati Planlaması \\
\hline
\end{tabular}

Tablo 4'ü incelediğimiz zaman, uzaktan öğretimin devam etmesi durumunda okuma yazma öğretiminde alınması gereken tedbirlerin teknoloji kapsamında yapılması gerekenler, aile kapsamında yapılması gerekenler, eğitim-öğretim etkinlikleri kapsamında yapılması gerekenler ve yetkililerce yapılması gerekenler olmak üzere dört tema ortaya çıkmıştır. Temalarımızı incelediğimizde, yetkililerce alınması gereken tedbirlerin diğer temalardan daha fazla kod içerdiğini görmekteyiz. Katılımcı öğretmenlerimizden bazılarına ait görüşlere aşağıda yer verilmiştir.

"Bu süreçte okuma yazma öğretiminin devam etmesi için eğitim öğretimin temel ilkelerinden fırsat eşitliği ilkesinin yerine getirilmesi gerekmektedir. Aksi taktirde Türkiye'nin batı kesimi ve merkezindeki öğrenci ve öğretmenler eğitim ve öğretim faaliyetlerine devam ederken doğu kesimindeki ve ücra köşelerdeki öğretmen ve öğrenciler kaderine terk edilecektir." (S.Ö.3, K)

"Birinci sınıflar için haftanın 2 günü okul açık kalması gerekiyor en azından 2 saat bile olsa gerekli dönütlerin verilmesi adına bu şekilde yapılması daha iyi olur." (S.Ö.7, E)

"Grafik tablet gibi ekranda düzgünce Türk temel harflerini yazabilecek bir teknolojinin bütün öğretmende olması gerektiğini ve internet uygulamalarında daha çok gelişim göstererek okuma yazma sürecinin en etkili şekilde işlenmesi." (S.Ö.11, K)

"Internet ve bilgisayarı olmayan ögrrenci kalmamalı. Hayat Bilgisi, Türkçe, Matematik ve Rehberlik dışında ders olmamalı. Haftada 30 saat ekran başında (bazısı telefon ekranı) oturan çocukta görme ve iskelet yapısında sorunlar oluşabilir. Öğretmenler için de aynı sorunlar mevcut." (S.Ö.14, E)

"Ders saatlerinin kısaltılması gerekmektedir. Birinci sınıf öğrencisinin 6 ders canlı derse katılması sürece olan hevesini kırıyor. Çok yoruluyorlar. Imkanları canlı derse katılmaya elverişli olmayan öğrenciler desteklenmeli." (S.Ö.24, K)

"Bu tedbirlerden bence en önemlisi fırsat eşitliğinin sağlanmasıdır. Evet uzaktan eğitim evet EBA evet Zoom belki çok faydalı kaynaklar ama ya bunlardan faydalanamayan öğrenciler ne olacak? şimdi okullara tablet dağıtılmasından bahsediliyor ne kadar da güzel fakat benim köyümdeki kırk öğrenciye tablet dağıtılsa ne olacak çocuklar internete giremediği takdirde? belirlenen uygulamaların yalnızca şehir merkezlerindeki durumu iyi öğrencilerin faydalanabileceği uygulamalar olduğunu düşünüyorum." (SÖ30, K)

"EBA veri tabanı geliştirilmelidir. Öğrencilere bilgisayar, tablet vb. canlı derse girebileceği teknolojik araçlar verilmeli. Internet ücretsiz olmalıdır. Gerisini öğretmenler halleder." (S.Ö.39. E)

"Veliler bilinçlendirilmeli ve eğitime tabi tutulmalıdır. Teknoloji eksikliği giderilmeli, internet hizmeti ücretsiz olmalıdır." (S.Ö.74, K)

"Uzaktan eğitim süresince özellikle 1.sınıflar için ne yapılırsa yapılsın okuldaki seviyeye ulaşmanın mümkün olduğunu düşünmüyorum. Ama en azından bütün öğrencilerin katılımı sağlansa yeterlidir. Ne yazık ki uzaktan eğitim sürecinde ülkemizdeki fırsat eşitsizliği gün yüzüne çıkmış bulunmaktadır. Fırsat eşitliği sağlayıp bütün öğrencilere ulaşabilirsek bu yeterlidir." (S.Ö.83, E)

"Materyaller ile destek sağlanmalı, öğretmenlere online süreçte çok daha etkili iletişim kurabilmeleri için online seminerler düzenlenmeli, bunun dışında online eğitim ve yüz yüze eğitim arasında çok büyük fark olduğu için içerik ve öğretim yöntemlerinin güncellenmesi gerekir." (S.Ö.98, K)

"Özellikle kırsal kesimde yaşayan öğrenciler tablet dağıtılıp internet sorunun halledilmesi. Kazanımlar çok fazla ve bu kazanımların tümü uzaktan eğitimle verilebilecek durumda değil, kazanımlar seyreltilerek özellikle daha önemli olan kazanımların verilmesi yeterlidir. Çocuklar somut işlemler döneminde olduğu için ekran başında tutma süreleri azaltılmalı. Der her bir dersin 30 dakika olması da çocukların dikkat ve motivasyonunu etkiliyor. Ders saati süreleri de düşürülebilir." (S.Ö.108, E) 


\section{Tartışma ve Sonuç}

Bu bölümde araştırma sonucunda elde edilen bulgulara bağlı olarak ortaya çıkan sonuçlar ele alınmış ve ilgili alanyazındaki farklı araştırmaların sonuçları ile tartışılmışıı. Bölüm sonunda araştırmacı tarafından alanyazına katkı sunması adına çeşitli önerilerde bulunulmuştur.

Bu araştırmanın amacı, Covid-19 salgını döneminde birinci sınıf öğretmenlerinin acil uzaktan eğitimle ilkokuma yazma öğretimine yönelik deneyimleri ile ilgili görüşlerini incelemektir. Alanyazında ilkokuma ve yazma özelinde, yaşanan Covid-19 salgını döneminde doğrudan birinci sınıf öğretmenlerinin deneyimlerinin incelendiği bir çalışmaya rastlanılmamıştır. 2019-2020 eğitim-öğretim yılının bahar döneminin yarısında başlatılan acil uzaktan eğitim modeline 2020-2021 eğitim-öğretim yılının güz döneminde de devam edilmesiyle birinci sınıf öğretmenleri ilk defa bu dönemde acil uzaktan eğitimle ilkokuma yazma öğretimine başlamışlardır. Bundan dolayı araştırmada birinci sınıf öğretmenlerinin deneyimleri ve görüşleri incelenmiş olup, ilerleyen dönemlerde ilkokuma yazma öğretiminin uzaktan yapılması konusunda ne gibi tedbirlerin alınması konusunda yeni fikirler verecektir.

Birinci sınıf öğretmenlerinin görüşlerine göre bu süreçte EBA, Zoom ve Youtube gibi programların varlığı eğitim-öğretimin devam etmesine hizmet etmiş olmasına rağmen, internete bağlanma sorunları, öğrencilerin herhangi bir dijital araca sahip olmaması ya da sahip oldukları araçların çok eski olması, yaşanan ses ve görüntü sorunları ve yer yer EBA'ya bağlanma sorunları nedeniyle ilkokuma yazma öğretiminde ciddi sorunlar yaşanmasına neden olmuştur. Bu noktada birinci sınıf öğretmenlerimiz kendi imkanları doğrultusunda hazırladıkları resim ve videodan oluşan görsellerle, web 2.0 araçlarını mümkün olduğunca kullanarak ve çevrimiçi dikte çalışmaları yaparak aşmaya çalışmışlardır. Bunlara ek olarak birinci sınıf öğretmenleri, ilerleyen dönemde uzaktan eğitimin ilkokuma yazma öğretiminde kullanımının devam etmesi, hatta kalıcı olması ihtimaline karşı teknoloji kapsamında alınması gereken tedbirleri yazııımların zenginleştirilmesi, altyapının güçlendirilmesi ve gerekli teknolojik araçların çocuklara temin edilmesi yönünde görüş bildirmişlerdir. Bilindiği üzere ilkokuma yazma öğretiminde çocuklara teknoloji dahil birçok kaynakla desteklenmesi önemlidir (Altunkaynak ve Çağımlar, 2020; Güneş ve Özerbaş, 2015). Orhan (2007) yaptığı araştırmada, bilgisayar destekli ilkokuma yazma eğitimi alan bir çocuğun becerilerine katkı sağladığı, buna bağlı olarak gereken altyapının temin edilerek, çeşitli yazılımlarla güçlendirilmiş bir eğitim programının ilkokuma ve yazma öğretimine daha çok katkı sağlayacağı sonuçlarına ulaşmıştır. Benzer şekilde Aslan (2020) ve Özcan ve Özcan (2016) yaptıkları çalışmada teknoloji destekli bir ilkokuma yazma öğretiminin çocukların akademik başarılarını artıracağı sonucuna ulaşmıştır. Burada karşımıza çıkan en önemli noktalardan biri, sınıf içi kullanıma uygun olan ilkokuma yazma öğretimini destekleyen teknolojilerin ve yazılımların, acil uzaktan eğitim modelinde ne kadar kullanılabilir olduğudur. Bu süreçte, birinci sınıf öğretmenlerinin birçoğu sınıf içi etkinliklerde kullanıma uygun yazılımları uzaktan eğitim sürecinde kullandıkları verdikleri örneklerden anlaşılmaktadır. Öğretmenlerin görüşlerinden ortaya çıkan sonuca göre, teknoloji kullanımı okuma yazma öğretimini desteklemesine rağmen bu yazılımlar acil uzaktan eğitim sürecinde öğretmenlere sınıf içi kullanım kadar destek sağlamamıştır. Bir diğer sonuç ise ilkokuma yazma öğretiminde kullanılan yazılım ve teknolojilerin, acil uzaktan eğitim sürecine uyarlanması gerekliliğidir.

Bununla beraber, Altunkaynak ve Çağımlar (2020) sınıf öğretmenlerinin "orta” seviyede dijital içeriklerle ilişkili olduğunu, sınıf öğretmenlerinin bu tür dijital içerik kullanımını artırmalarını tavsiye etmektedirler. Buna ek olarak, öğretmenlerin bireysel teknolojik yeterlik eksikliklerinin olduğunu belirten çalışmalar da vardır (Geçgel, Kana ve Eren, 2020). Ayrıca teknolojik-pedagojik alan bilgisi kapsamında değerlendirilmesi gereken teknolojiyi doğru amaçlarla kullanabilme becerisinin öğretmenlere verilmesi gerekliliği ortaya çıkmıştır. Bakioğlu ve Çevik (2020) yaptığı çalışmada salgın döneminde öğretmenlerin eğitim-öğretim etkinliklerinde teknolojiyi kullanmaya dair tutumlarının olumlu bir şekilde değiştiği sonucuna ulaşmışlardır. Öğretmenlerin teknolojiye dair bilgilerinin artıııması ve ilkokuma yazma öğretiminde doğru ve etkili bir şekilde kullanımına dair eğitim almaları gerekmektedir. Öğretmenlerin talepleri doğrultusunda yazılım ve teknolojik araç olarak güçlendirilmiş bir eğitim-öğretim ortamı, salgın neticesinde ortaya çıkan acil uzaktan eğitim modeliyle ilkokuma yazma öğretimine olumlu katkılar sunacağı düşünülmektedir. Bu noktada acil olarak öğretmenlerin 
eksiklikleri tespit edilmeli, gereken araçlar ve eğitimler uzaktan eğitim modeli kullanılarak kendilerine verilmelidir.

Birinci sınıf öğretmenleri, bu dönemde çaba gösteren velilerin varlığı ve bu velilerin öğrenciyi öğrenmeye teşvik etmeleri, zor şartlarda olsalar dahi araç gereç temin etme çabası gösteren velilerin varlığı, kendilerine yardım eden en temel unsurlardan biri olduğunu bildirmişlerdir. Bunun yanında, ilgisiz, öğrencinin derse katılımını veya geç katılımını umursamayan, acil uzaktan eğitimi eğitimden saymayıp tatil gibi gören velilerde bu dönemde kendilerine sorun çıkaran, aile kaynaklı etmenler olarak belirlemişlerdir. Covid-19 salgını dolayısıyla eğitim-öğretim faaliyetlerinin yolunda ilerlemesi için ailelerin yeterince bilinçlendirilmesi, çocukların ekranı eğitim amaçlı kullanabilmelerine nasıl yardımcı olacakları konusunda bilgilendirilmeleri gerektiği de bu sürecin ortaya çıkardığı sonuçlardandır (Reimers ve Schleicher, 2020; Garbe, Ogurlu, Logan ve Cook, 2020). Bu sonuçlarla örtüşen bulgulara ulaştı̆̆ımız çalışmada, acil uzaktan eğitim yoluyla daha da zorlaşan ilkokuma yazma öğretiminin doğru bir şekilde ilerlemesi adına velilere bir eğitim verilmesi gerçeği ortaya çıkmaktadır. Bu sürecin devam etmesi durumunda, katılımın öneminin ailelere kabul ettirilmesi ve ailelere eğitim-öğretim etkinliklerini yürütmede yardımcı olmalarını sağlayacak eğitimin verilmesinin acil uzaktan eğitimde yaşanan sorunlara karşı muhtemel çözüm yolları olmaları yönünde görüş bildirmişlerdir. Bu noktada atılması gereken en önemli adımlardan bir tanesi, velilerin acil uzaktan eğitim-öğretim faaliyetlerini yakından takip etmeleri konusunda Millî Eğitim Bakanlığı ve diğer ilgili kurumların sağlayacağı eğitimlerle bilinçlendirilmeli, her velinin şartlarını zorlayarak çocuğunun gelişimini takip edip öğretmenleriyle sürekli bir fikir alışverişinde olmaları gerektiği konusunda bilgilendirilmelilerdir.

Akyol'un (2015) belirttiği üzere, okuma yazma ve dil gelişiminde aileler öğretmenlere en büyük yardımcı konumundadır. Bu salgın sürecinde bu rolün önemi daha da artmış bulunmaktadır. Yapılan araştırmalardan Ekici-Calın (2019)'ın çalışmasını incelediğimizde, ilkokuma yazma öğretiminde velilerin ses temelli cümle yöntemine dair bilgilerinin yeterli düzeyde olmadığını; bu sorunu gidermek adına ses temelli cümle yöntemi hakkında bilgilendirilmelerinin önemli olduğu sonucuna varmıştır. Benzer bir şekilde Bayat (2014) yaptığı çalışmada ilgisiz veya yeterli destek vermede güçlük yaşayan velilerin varlığı, ilkokuma yazma öğretiminde çeşitli olumsuzluklara yol açtığı sonucuna ulaşmıştır. Bu sorunları aşmanın yolunun velilerin program ve ilkokuma yazma öğretimi hakkında bilgilendirilmesinden geçtiğini bildirmiştir. Burada bütün velilerin çocuklarına eğitim verebilecek seviyede olmasını beklemek yanlış olabilir; ancak Millî Eğitim Bakanlığı tarafından geliştirilmeye devam eden EBA programı üzerinde ya da alternatif platformlarda, bütün velilerin ya da çocukların yanında var olan yetişkinlerin anlayacağı bir dilde ilkokuma ve yazma öğretimi sürecinin anlatıldı̆̆ı, süreçte nelere dikkat edilmesi gerektiğini anlatan kısa video kayıtları eklenebilir. Asgari düzeyde bir bilgi olsa dahi, çocukların okuma yazma süreçlerini daha bilinçli takip etmeleri sağlanabilir.

Ayrıca bu dönemde morpa kampüs ve okulistik gibi çevrimiçi öğrenme ortamları, çeşitli elektronik ve yardımcı kaynaklar ile ilkokuma yazma öğretimine özelleştirilerek kullanılabilen web 2.0 araçları ve yabancı internet sayfalarından çeviri yaparak kullandıkları yöntemler eğitim-öğretim faaliyetlerini mümkün olduğunca aksatmadan götürmek isteyen öğretmenlere yardımcı olmuşlardır. Bununla beraber, öğretmenler eğitim amaçlı teknolojiyi kullanmadaki bilgi eksikliği, öğrencileriyle yaşadıkları etkileşimin istenilen düzeyde olmaması, verilmek istenen eğitim için ayrılan sürelerdeki kısıtııık, öğrencilerin çalışmalarını değerlendirmede yaşanılan güçlükler, öğrencilerin derse katılımındaki kayıplar ve sınıf ortamını çevrimiçi olarak kontrol etmedeki güçlüklerle mücadelenin eğitim-öğretimi zorlaştırdığını bildirmişlerdir. Uzaktan eğitimin devam etmesi durumunda, hibrit eğitim modelinin benimsenmesinin, kendilerine yönelik verilecek teknolojik-pedagojik alan bilgisinin, güncel duruma uygun yazılı ve çevrimiçi materyallerin geliştirilmesinin ve son olarak bedensel etkinliklerin de planlanmasının yaşanılan salgın dönemini daha zararsız olarak atlatılmasına yardımcı olacağını düşünmektedirler. Yapılan son çalışmalarda, öğretmenlerin acil uzaktan eğitime bakış açılarında, en azından iletişim kurma kanalı olarak kullanılmasına bağlı olarak olumlu gelişmelerin olduğunu gösteren bulgularla birlikte (Çiftçi, Temel, Yeganeh, Sarı ve Soydemir-Bor,2020; Pınar ve Dönel-Akgül, 2020; Sarı ve Nayır, 2020), öğretmenlerin hibrit eğitim modeliyle eğitim-öğretim faaliyetlerini devam ettirmesinin akademik başarılarını sürdürmelerine adına öğrencilere yardımcı olacağını söyleyen bulgular da vardır (Korucu ve Kabak, 2020). Covid-19 salgını nedeniyle alınan 
tedbirlerin ne kadar uzayacağı konusunda kesin bir bilgiye ulaşmak an itibariyle çok zordur. Bu nedenle eğitim-öğretim faaliyetlerinin planlanmasında alternatif yöntemler göz önünde bulundurulmalı, belli zamanlarda yüz yüze, belli zamanlarda da uzaktan eğitim modelinin uygulanabileceği bir hibrit model üzerinde de çalışmalar yürütülmelidir.

Ses temelli cümle yöntemini acil uzaktan eğitimle vermeye çalışan birinci sınıf öğretmenlerinin en çok hecelerden kelimeler oluşturma ve seslerden heceler oluşturma basamaklarında zorlandıkları görülmüştür. En az ise ilkokuma yazmaya hazırlık basamağında zorlandıkları görülmüştür. Bu basamakta daha az zorlanmalarını, tamamen acil uzaktan eğitim modeline geçilmeden önce, dönemin başından itibaren önce haftada bir gün, takip eden haftalarda iki gün çocukların okula gitmesiyle ortaya çıkan bir sonuç olarak yorumlayabiliriz. Illkokuma yazma öğretiminin takip etmesi gereken basamaklarında sorunlarla karşılaşıldığını gösteren çalışmalar alanyazında mevcuttur (Başar ve TanışGürbüz, 2020; Özcan ve Özcan, 2016). Buna son olarak acil uzaktan eğitimin işin içine girmesiyle, ilkokuma yazma öğretiminde karşılaşılan zorlukların daha da arttığı görülmektedir. Birinci sınıf öğretmenlerinin bu güçlükleri aşmak için görsellerden yararlanma, veli ile işbirliği içinde olma, web 2.0 araçlarının kullanımı, oyunlaştırma ve ders dışı ödevlendirme gibi yöntemlere sıklıkla başvurduklarını söylemişlerdir. illgili alanyazın incelendiğinde, eğitim teknolojilerinden yararlanmanın, veli ile doğru yollarla iletişime geçerek okuma yazma öğretimini sürdürmenin ve oyunla desteklemenin olumlu yönlerinin olduğunu gösteren çalışmalar bulunmaktadır (Babayiğit ve Erkuş, 2017; Babayiğit ve Gültekin, 2019, Fauzi ve Khusuma, 2020). Buna acil uzaktan eğitimin meydana getirdiği durumla değerlendirdiğimizde, ilkokuma yazma öğretiminde bu yöntemlerin teknoloji merkezli olarak değişime uğraması gerekliliği sonucu ortaya çıkmaktadır. Bu noktada yukarıda da belirtildiği üzere, velilerle sürekli iletişim içinde olarak çocuğun ses temelli cümle yönteminin hangi aşamasında daha fazla zorluk yaşadığı tespit edilmeli, veli-öğretmen işbirliği içerisinde bu sorunlara muhtemel çözümler aranmalıdır. Piyasada var olan ses temelli cümle yöntemiyle okuma yazma öğreten yazılımların kullanımı konusunda da öğretmenler ve veliler dikkatli olmalıdır. Kartal vd. (2017), yaptıkları araştırmada, çeşitli yazılım şirketleri tarafından okuma yazma öğretimi için geliştirilen yazılımları birçok içerik ve teknik anlamında okuma yazma öğretimini destekler nitelikte olmadıklarını ve gereksinimleri karşılamadıklarını tespit etmişlerdir. Bu tespitler göz önünde bulundurularak öğretmenler ve veliler kullanacakları yazılımları dikkatle seçmeli, zor işleyen bir sürecin telafisi daha da zor olabilecek boyutlara dönüşmesinin önüne geçmelidirler.

Son olarak, acil uzaktan eğitiminin devamında ortaya çıkabilecek bir uzaktan eğitim modelinin kalıcı duruma dönüşmesiyle, ilkokuma yazma öğretiminin daha etkili ilerlemesi adına yapılması gerekenlerin ne olduğunu sorduğumuz birinci sınıf öğretmenlerimize göre zengin bir yazılım altyapısına sahip olmak, güçlü bir internet altyapısı ve teknolojik araç zenginliği, eğitim-öğretim faaliyetlerini güçlendirmek adına aile eğitimine önem verilmesi, fırsat eşitliğinin sağlanması, güncel bir program içeriğinin hazırlanması, sınıf kontenjanlarının düşürülerek katılımın artırılması, yeni ders saati planlamalarının yapılması, gerektiği yerde yüz yüze telafi programlarının oluşturulması ve ne olursa olsun normalleşme sürecinin hızlandırılması gerekmektedir. Ortaya çıkan bu ani durum karşısında, eğitim-öğretimin aksamaması hızla araştırmalar yapan bilim insanlarının bulgularını incelediğimiz zaman da benzer beklentilerle karşılaşmaktayız (Arslan ve Şumuer, 2020; Bakioğlu ve Çevik, 2020; Bozkurt 2020a; Bozkurt 2020b; Can, 2020; Daniel, 2020; Demir ve Özdaş, 2020; Duman, 2020; Eken vd., 2020; Günbaş ve Gözüküçük, 2020; Kalaç, Telli ve Erönal, 2020; Kantos, 2020; Keleş, Atay ve Karanfil, 2020; Korkmaz ve Toraman, 2020; Kurnaz vd., 2020; Külekçi-Akyavuz ve Çetin, 2020; Sarı ve Nayır, 2020; Yıldız ve Akar-Vural, 2020; Yurtbakan ve Akyıldız, 2020). Talepler ve alanyazında ortaya çıkan benzer beklentiler doğrultusunda gerekli yetkili birimler ilgili adımları atmalı, eğitim-öğretim faaliyetlerinin zarar görmeden devam etmesini temin etmelidirler. Bilinen bir gerçek var ki, o da her ne olursa olsun, yaşanan bu süreçte öğrencilerin eğitim-öğretim faaliyetlerine devam etmesi gerekmektedir (Reimers ve Schleicher, 2020).

Araştırmanın sonuçlarına bağıı olarak aşağıdaki önerilerde bulunulabilir;

1. Teknoloji, internet ve yazılım kaynaklı acil uzaktan eğitimin önemli unsurlarına ulaşım noktasında fırsat eşitliği tüm öğrencilere temin edilip, eksiksiz şekilde eğitim-öğretim etkinliklerine devam etmeleri sağlanabilir. 
2. Çocuğun yaşadığı çevreden kaynaklı derslere katılım oranları düşük olmaktadır. Gerek aile gerekse çocuğun çevresi derse katılım konusunun önemi hakkında bilgilendirilmeli, çocuğun çevrimiçi derslere katılımına özen göstermelilerdir.

3. Ders programları ve içerikleri güncel gelişmeler doğrultusunda yeniden ele alınmalı, gerekli değişiklikler ve eklemeler yapılarak acil uzaktan eğitim ve sonrasında gelebilecek uzaktan eğitim modellerine uygun duruma getirilebilir.

4. Gerekli yetkili birimler sınıf kontenjanlarını yeniden düzenlemek dahil olmak üzere, atılması gereken adımları alanında uzman kişilerle belirleyip derslerin daha etkili olması yönünde müdahalelerde bulunabilirler.

5. Sadece ilkokuma yazma öğretimi aşamasında değil, ilkokuldan liseye kadar her öğrenim seviyesinde uzaktan eğitime dair ihtiyaçların belirlenmesine dair çalışmalar yapılabilir.

\section{Araştırma ve Yayın Etiği}

Bu çalışmada "Yükseköğretim Kurumları Bilimsel Araştırma ve Yayın Etiği Yönergesi" kapsamında uyulması belirtilen tüm kurallara uyulmuştur. Yönergenin ikinci bölümü olan "Bilimsel Araştırma ve Yayın Etiğine Aykırı Eylemler" başlığı altında belirtilen eylemlerden hiçbiri gerçekleştirilmemiştir. Çalışmaya katılan sınıf öğretmenlerinden gönüllülük esasına göre izinleri alınmıştır.

\section{Etik Kurul İni}

Kurul adı $=$ Çanakkale Onsekiz Mart Üniversitesi Bilimsel Araştırmalar Etik Kurulu

Karar tarihi $=04.12 .2020$

Belge sayı numarası $=06 / 31$

\section{Yazarların Katkı Oranı}

Çalışma tek yazarlı olup bütün araştırma sorumlu yazara aittir.

\section{Çıkar Çatışması}

Bu araştırmada çıkar çatışması teşkil edebilecek herhangi bir durum ya da ilişki yoktur.

\section{Kaynaklar}

Akkaş-Baysal, E. ve Ocak, G. (2020). Covid-19 salgını sonrasında okul kavramındaki paradigma değişimine ve okulların yeniden açılmasına ilişkin öğretmen görüşleri. Türk Eğitim Bilimleri Dergisi, 18(2), 172-201. doi: 10.37217/tebd.787504

Akyol, H. (2015). Türkçe ilk okuma ve yazma öğretimi. Ankara: Pegem Akademi.

Altunkaynak, M. ve Çağımlar, Z. (2020). Sınıf öğretmenlerinin ilkokuma yazma öğretiminde eğitim teknolojilerini kullanma ve eğitsel olarak faydalanma durumları. Milli Eğitim Dergisi, 49(226), 93-122.

Arslan, Y. ve Şumuer, E. (2020). Covid-19 döneminde sanal sınıflarda öğretmenlerin karşılaştıkları sınıf yönetimi sorunları. Milli Eğitim Dergisi, 49(1), 201-230. doi: 10.37669/milliegitim.791453

Aslan, S. (2020). Sınıf öğretmeni adaylarının ilkokuma yazma öğretiminde animasyon ve simülasyon kullanımına yönelik deneyimleri ile ilgili görüşleri. Ana Dili Eğitimi Dergisi, 8(4), 1133-1148. doi: 10.16916/aded.756564

Babayiğit, Ö. ve Erkuş, B. (2017). Problems and solutions in literacy training process. Erzincan Üniversitesi Eğitim Fakültesi Dergisi, 19(2), 271-284. doi: 10.17556/erziefd.334982

Babayiğit, Ö. ve Gültekin, M. (2019). Illk okuma yazma öğretiminde oyunla öğretim yöntemi uygulamaları. Anadolu Journal of Educational Sciences International, 9(2), 450-483. https://doi.org/10.18039/ajesi.577376

Bakioğlu, B. ve Çevik, M. (2020). COVID-19 pandemisi sürecinde fen bilimleri öğretmenlerinin uzaktan eğitime ilişkin görüşleri. Turkish Studies, 15(4), 109-129. doi: 10.7827/TurkishStudies.43502

Başar, M. ve Tanış-Gürbüz, H. (2020). illk okuma ve yazma öğretiminde karşılaşılan sorunlar ve çözüm önerileri. Okuma Yazma Eğitimi Araştırmaları, 8 (1), 1-20. doi: 10.35233/oyea.666563 
Bayat, S. (2014). Sınıf öğretmenlerinin ilkokuma yazma programının uygulanmasında karşılaştıkları güçlüklere ilişkin görüşleri. ilköğretim Online, 13(3), 759-775.

Bozkurt, A. (2020a). Koronavirüs (Covid-19) pandemi süreci ve pandemi sonrası dünyada eğitime yönelik değerlendirmeler: Yeni normal ve yeni eğitim paradigması. Açıköğretim Uygulamaları ve Araştırmaları Dergisi, 6(3), 112-142.

Bozkurt, A. (2020b). Koronavirüs (Covid-19) pandemisi sırasında ilköğretim öğrencilerinin uzaktan eğitime yönelik imge ve algıları: Bir metafor analizi. Uşak Üniversitesi Eğitim Araştırmaları Dergisi, 6(2), 1-23. doi: 10.29065/usakead. 777652

Bozkurt, A. ve Sharma, R. C. (2020). Emergency remote teaching in a time of global crisis due to CoronaVirus pandemic. Asian Journal of Distance Education, 15(1), i-vi.

Bozkurt, A., Jung, I., Xiao, J., Vladimirschi, V., Schuwer, R., Egorov, G. ve ark. (2020). A global outlook to the interruption of education due to COVID-19 Pandemic: Navigating in a time of uncertainty and crisis. Asian Journal of Distance Education, 15(1), 1--126.

Büyüköztürk, Ş., Kılıç-Çakmak, E., Akgün, Ö.E., Karadeniz, Ş. ve Demirel, F. (2020). Bilimsel araştırma yöntemleri (28. baskı). Ankara: Pegem Akademi.

Can, E. (2020). Coronavirüs (Covid-19) pandemisi ve pedagojik yansımaları: Türkiye'de açık ve uzaktan eğitim uygulamaları. Açıköğretim Uygulamaları ve Araştırmaları Dergisi, 6(2), 11-53.

Creswell. J.W. (2012). Educational research: Planning, conducting, and evaluating quantitative and qualitative research. Boston: Pearson.

Çiftçi, S., Temel, M., Yeganeh, E., Sari, B. ve Soydemir-Bor, S. (2020, Kasım). COVID-19 pandemi döneminin öğretmen, öğrenci ve velilere yansıması. M. Zhurba (Ed.), X. International Scientific and Practical Conference Kongre Kitabı (120-133). Ukraine: NGO Sobornist.

Daniel, S. J. (2020). Education and the Covid-19 pandemic. Prospects,49, 91-96.

Darling-Hammond, L. ve Hyler, M. E. (2020). Preparing educators for the time of COVID... and beyond. European Journal of Teacher Education, 43(4), 457-465. doi: 10.1080/02619768.2020.1816961

Demir, F. ve Özdaş, F. (2020). Covid-19 sürecindeki uzaktan eğitime ilişkin öğretmen görüşlerinin incelenmesi. Milli Eğitim Dergisi, 49(1), 273-292. doi: 10.37669/milliegitim. 775620

Duman, S. (2020). Salgın döneminde gerçekleştirilen uzaktan eğitim sürecinin değerlendirilmesi. Milli Eğitim Dergisi,49(1), 95-112. doi: 10.37669/milliegitim.768887

Eken, Ö., Tosun, N. ve Tuzcu-Eken, D. (2020). Covıd-19 salgını ile acil ve zorunlu uzaktan eğitime geçiş: Genel bir değerlendirme. Milli Eğitim Dergisi,49(1), 113-128. doi: 10.37669/milliegitim.780722

Ekici-Calın, T. (2019). Sınıf Öğretmenlerinin ilkokuma-Yazma Öğretimine ilişkin Görüşleri (Yayımlanmamış yüksek lisans tezi). Hacettepe Üniversitesi Eğitim Bilimleri Enstitüsü, Ankara.

Fauzi, I. ve Khusuma, I. H. S. (2020). Teachers' elementary school in online learning of COVID-19 pandemic conditions. Jurnal Iqra': Kajian Ilmu Pendidikan, 5(1), 58-70. doi: 10.25217/ji.v5i1.914

Garbe, A., Ogurlu, U., Logan, N. ve Cook, P. (2020). Parents' experiences with remote education during COVID-19 school closures. American Journal of Qualitative Research, 4(3), 45-65. doi: 10.29333/ajqr/8471

Geçgel, H., Kana, F. ve Eren, D. (2020). Türkçe eğitiminde dijital yetkinlik kavramının farklı değişkenler açısından incelenmesi. Ana Dili Eğitimi Dergisi, 8(3), 886-904. doi: 10.16916/aded.742352

Günbaş, N. ve Gözüküçük, M. (2020). Views of elementary school children's parents about distance education during the Covid-19 pandemic. Sakarya University Journal of Education, 10 (3), 686716. doi: $10.19126 /$ suje. 789705

Güneş, A. ve Özerbaş, M. (2015). Sınıf öğretmenlerinin ilk okuma yazma sürecinde eğitim teknolojilerini kullanmaya yönelik görüşleri. Kastamonu Eğitim Dergisi, 23(4), 1775-1788.

Hodges, C., Moore, S., Lockee, B., Trust, T. ve Bond, A. (2020, March 27). The difference between emergency remote teaching and online learning. Educause Review. Erişim adresi: https://er.educause.edu/articles/2020/3/the-difference-between-emergency-remote teaching-and-online-learning. 
Kalaç, M. Ö., Telli, G. ve Erönal, Y. (2020). Covid-19 mücadelesi kapsamında uzaktan eğitim sürecinde engelli öğrencilerin durumu sorunlar ve çözüm önerileri. M.Ö. Kalaç; G. Telli ve Y. Erönal (Eds). Manisa: MCBÜ Rektörlük Basımevi.

Kartal, H., Baltacı-Göktalay, Ş. ve Sungurtekin, Ş. (2017). Okuma yazma öğretimine yönelik eğitsel yazılımların çok boyutlu değerlendirilmesi. Abant Izzet Baysal Üniversitesi Eğitim Fakültesi Dergisi, 17 (4), 1938-1956. doi: 10.17240/aibuefd.2017.17.32772-363977

Keleş, H., Atay, D. ve Karanfil, F. (2020). Covid 19 pandemi sürecinde okul müdürlerinin öğretim liderliği davranışları. Milli Eğitim Dergisi ,49(1), 155-174. https://doi.org/10.37669/milliegitim.787255

Korkmaz, G. ve Toraman, Ç. (2020). Are we ready for the post-COVID-19 educational practice? An investigation into what educators think as to online learning. International Journal of Technology in Education and Science (IJTES), 4(4), 293-309. doi: 10.46328/ijtes.v4i4.110

Korucu, A. ve Kabak, K. (2020). Türkiye'de hibrit öğrenme uygulamaları ve etkileri: Bir meta analiz çalışması. Bilgi ve iletişim Teknolojileri Dergisi, 2(2), 88-112.

Kurnaz, A., Kaynar, H., Şentürk Barışık, C. ve Doğrukök, B. (2020). Öğretmenlerin uzaktan eğitime ilişkin görüşleri. Milli Eğitim Dergisi, 49(1), 293-322. doi: 10.37669/milliegitim.787959

Külekçi-Akyavuz, E. ve Çakın, M. (2020). Covid-19 salgınının eğitime etkisi konusunda okul yöneticilerinin görüşleri. Turkish Studies, 15(4), 723-737. doi: 10.7827/TurkishStudies.44140

Orhan, H. G. (2007). Bilgisayar destekli öğretimin ilkokuma yazma başarısına etkisi (Yayımlanmamış yüksek lisans tezi). Marmara Üniversitesi Eğitim Bilimleri Enstitüsü, İstanbul.

Özcan, A. F. ve Özcan, A. O. (2016). Illk okuma yazma öğrenmede çocukların yasadıkları güçlükler, nedenleri ve çözüm önerileri: Nitel bir araştırma. İstanbul Gelişim Üniversitesi Sosyal Bilimler Dergisi, 3 (1), 69-103.

Pınar, M. A. ve Dönel-Akgül, G., (2020). The opinions of secondary school students about giving science courses with distance education during the Covid-19 pandemic. Journal of Current Research on Social Sciences, 10(2), 461- 486. doi: 10.26579/jocress.377

Reimers, F. M. ve Schleicher, A. (2020). A framework to guide an education response to the COVID-19 Pandemic of 2020. OECD Report. Erişim adresi: https://oecd.dambroadcast.com/pm_7379_126_126988-t63lxosohs.pdf.

Sarı, T. ve Nayır, F. (2020). Pandemi dönemi eğitim: sorunlar ve fırsatlar. Turkish Studies, 15(4), 959975. doi: 10.7827/TurkishStudies.44335

Sirem, Ö. ve Baş, Ö. (2020). Okuma güçlüğü olan ilkokul öğrencilerinin Covid-19 sürecinde uzaktan eğitim deneyimleri. Turkish Studies, 15(4), 993-1009. doi: 10.7827/TurkishStudies.43346

United Nations Educational, Scientific and Cultural Organization. (2020a). School closures caused by Coronavirus (Covid-19). UNESCO. Erişim adresi: https://en.unesco.org/covid19/educationresponse.

United Nations Educational, Scientific and Cultural Organization. (2020b). Startling digital divides in distance learning emerge. UNESCO. Erişim adresi: https://en.unesco.org/news/startlingdigital-divides-distance-learning-emerge.

World Health Organization. (2020). Coronavirus disease (COVID-19) Pandemic. World health Organization. Erişim adresi: https://www.who.int/emergencies/diseases/novel-coronavirus2019.

www.wordart.com

Yıldıım, A. ve Şimşek, H. (2018). Sosyal bilimlerde nitel araştırma yöntemleri. Ankara: Seçkin yayıncılık.

Yıldız, A. ve Vural, R. A. (2020). Covid-19 pandemisi ve derinleşen eğitim eşitsizlikleri. TTB Covid-19 Pandemisi Altıncı Ay Değerlendirme Raporu (556-565).

Yurtbakan, E. ve Akyıldız, S. (2020). Sınıf öğretmenleri, ilkokul öğrencileri ve ebeveynlerin Covid-19 izolasyon döneminde uygulanan uzaktan eğitim faaliyetleri hakkındaki görüşleri. Turkish Studies, 15(6), 949-977. doi: 10.7827/TurkishStudies.43780 


\section{Introduction}

\section{Extended Abstract}

After its initial emergence in Wuhan, China in December 2020, COVID-19 was officially declared a world-wide pandemic on March 11, 2020 by the World Health Organization ([WHO], 2020), at which point countries around the world began taking diverse measures to deal with the pandemic and devise strategies to curb or completely halt the pandemic. The subsequent measures taken in response to this pandemic were not solely health related; they included measures taken in the social, political, economic, and educational domains (Reimers \& Schleicher, 2020). These actions have resulted in the education of 1.6 billion students being interrupted in one form or another (UNESCO, 2020a), with nearly the entire world being affected by the current situation. In her own efforts to combat the pandemic, Turkey has begun to provide education online through what has been dubbed emergency distance learning (Bozkurt, 2020a; Bozkurt et al., 2020; Bozkurt \& Sharma, 2020; Hodges et al., 2020) in which approximately 16 million PreK-12 students currently take part (UNESCO, 2020b).

Upon investigation of the studies conducted on primary-school teachers during the COVID-19 pandemic, we discovered that teachers complained about problems related to Internet-connection, a lack of objective assessment criteria, the inability to know for sure whether students were or were not learning, the inability to go into greater depth on specific topics, the inability to conduct entertaining activities, the inability to account for individual differences, and passive students who only listened to the teacher during online classes (Fauzi \& Khusuma, 2020; Yurtbakan \& Akyıldız, 2020). After considering the problems faced by primary-school teachers, we concluded it to be necessary to inquire into the particular difficulties faced by first-grade classroom teachers during the COVID-19 pandemic.

The impetus behind this study was to investigate the difficulties caused by the distancelearning program implemented during this period given that the skills learned. During this period, particularly children's initial reading and writing experiences, will affect their academic performance for the remainder of their lives. Additionally, this study has aimed to identify what steps teachers have taken toward remedying these problems and to determine what measures should be prioritized in the likely event that distance learning continues. To this end, answers to the following questions have been sought:

1. What factors were helpful to first-grade teachers in teaching initial reading and writing via the distance-learning program implemented during the COVID-19 pandemic?

2. What factors were hurdles to first-grade teachers in teaching initial reading and writing via the distance-learning program implemented during the COVID-19 pandemic?

3. In which stage or stages of the sound-based sentence method did first-grade teachers encounter problems via the distance-learning program implemented during the COVID-19 pandemic? What steps did they take to overcome these problems?

4. In the event that the distance-learning program should continue, what measures do first-grade teachers believe should be taken to ensure that initial reading and writing education may continue?

\section{Method}

Following a qualitative research model design, this study employed snowball sampling - a type of purposeful sampling method-to select participants for inclusion. The participants of this study consisted of 111 first-grade primary teachers serving in all seven of Turkey's geographical regions during the fall semester of the 2020-2021 academic year who had volunteered to complete the online form devised for this study. Data were collected using a survey form and then subject to content analysis. A four-stage analysis defined by Yıldırım and Şimşek (2012) was employed in this study. During the first stage of this analysis, the entirety of the data was analyzed and then divided into segments whose underlying meanings were then identified. These meaningful segments were then coded with appropriate names. Following this, the author amassed these codes into a single database and separated them into specific categories so as to obtain themes for the data. The qualitative data analysis software MAXQDA was used during this phase, and the resulting codes were converted into 
word clouds. The themes that emerged from these codes were then depicted in chart form in the findings section.

\section{Results and Discussion}

In response to the first sub-problem of the study, first-grade teachers' opinions on what factors were helpful during the emergency distance-learning program were solicited; these were: parents, Internet resources, technological devices (e.g., computers, tablets, telephones), EBA, school administrators, ancillary resources, YouTube, department colleagues, web 2.0 tools, WhatsApp, Zoom, textbooks, social media, Morpa Kampüs, motivated students, Okulistik, electronic books, foreign language knowledge, and university students who were able to help their family members. In response to the second sub-problem, first-grade teachers' opinions on what factors acted as hurdles during the emergency distance-learning process were solicited; these were: inadequate Internet connectivity, lack of technological devices, indifferent parents, socio-economic issues, inadequate student participation, lack of knowledge on how to use educational technologies, inadequate hardware, inadequate interaction with students, inadequate parental knowledge, inadequate time for planning, lack of student motivation, student tardiness, difficulties in assessing students, institutional pressure, audio and visual problems, the notion that distance learning was not a real form of education, school administrators, lack of control, crowded classes, difficulties related to life at home, EBA connection problems, inadequate professional support, and demanding schedules. In response to the third subproblem, first-grade teachers were asked which of the required steps of the sound-based sentence method used during distance learning caused them the greatest difficulties. An analysis of teachers' responses to this question revealed that they had the greatest difficulties, respectively, forming words from syllables, forming syllables from sounds, forming sentences from words, composing written texts, starting initial reading and writing, perceiving and recognizing sounds, reading and writing sounds, and preparing for initial reading and writing activities.

After asking first-grade teachers what they thought would be necessary if the current emergency distance-learning model were to be converted into a permanent model in the future, they cited the following: a rich software infrastructure, a strong Internet infrastructure and wide array of technological devices, education provided to families so as to help improve the effectiveness of instructional activities, ensuring equality of opportunity, preparing up-to-date curricula and content, increasing in-class participation by reducing total class size, rearranging class schedules, implementing face-to-face tutoring programs where necessary, and, most importantly, accelerating the normalization process.

The following recommendations may be made based on the study's conclusions:

1. Students should all have equal access to the technology, Internet connection, and software needed to make full use of distance learning, as this will allow them to participate fully in instructional activities.

2. Children's attendance is low as a result of their environment. Children's family and environment should be made aware of the importance of attending distance-learning classes.

3. Course curricula and content should be reviewed and updated so that they are in-line with the latest developments. Doing this will make curricula and content more suitable to the current emergency distance-learning program and to any subsequent distance-learning models.

4. The necessary authoritative bodies should consult field experts to determine what steps should be taken and what interventions should be made, including adjustments in class size, so that lessons may be more beneficial for students.

5. Researchers can conduct specialized studies to determine the individual needs of each subject and grade level. 